NBER WORKING PAPER SERIES

WERE SMALL-TOWN NEW YORKERS LIFE-CYCLE SAVERS?

\author{
Howard Bodenhorn \\ Working Paper 28810 \\ http://www.nber.org/papers/w28810 \\ NATIONAL BUREAU OF ECONOMIC RESEARCH \\ 1050 Massachusetts Avenue \\ Cambridge, MA 02138 \\ May 2021, Revised November 2021
}

I thank Bill Dougan, Rob Fleck, Jorge Garcia, Mike Makowsky, and the participants in Clemson's Public Economics workshop for valuable comments on earlier drafts. The views expressed herein are those of the author and do not necessarily reflect the views of the National Bureau of Economic Research.

NBER working papers are circulated for discussion and comment purposes. They have not been peer-reviewed or been subject to the review by the NBER Board of Directors that accompanies official NBER publications.

(C) 2021 by Howard Bodenhorn. All rights reserved. Short sections of text, not to exceed two paragraphs, may be quoted without explicit permission provided that full credit, including $($ ) notice, is given to the source. 
Were Small-Town New Yorkers Life-Cycle Savers?

Howard Bodenhorn

NBER Working Paper No. 28810

May 2021, Revised November 2021

JEL No. N21

\begin{abstract}
Theories of household saving, including the life cycle hypothesis, posit that households add or draw down wealth to equalize the value of consumption over time. This article examines the extent to which late-nineteenth-century, small-town Americans accumulated financial assets consistent with the life cycle hypothesis. Using individual account records from a small-town savings banks, I find that savers accumulated an average of one year's income at age sixty. Decumulation was slower than expected after age sixty. The evidence is inconsistent with a strong bequest motive, so the slow drawing down of wealth in old age may have been due to uncertain mortality risk or wealth-based attrition from the sample. I find differences in the life cycle accumulations between men and women, the native- and foreign-born, and low-skill and high-skill workers.
\end{abstract}

\author{
Howard Bodenhorn \\ John E. Walker Department of Economics \\ 309-H Wilber O. and Ann Powers Hall \\ Clemson University \\ Clemson, SC 29634 \\ and NBER \\ bodenhorn@gmail.com
}




\section{Introduction}

Since at least Ramsey’s (1928) derivation of a mathematical model of saving in which individuals start their working life without assets, end without any, and purchase annuities in the interim to provide for later consumption, economists have modeled all types of choices, including consumption, saving, education, labor supply, marriage, and fertility, using life-cycle frameworks (Browning and Crossley 2001). In its most catholic form, the life cycle approach posits that people make sequential decisions regarding intertemporal allocations of effort and consumption to achieve a reasoned and established goal based on available information. A common invocation of a life-cycle approach involves a person’s saving decisions made during a working life so that he or she can smooth the marginal utility of consumption over time when income, health, productivity, and age at retirement is

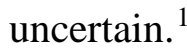

For an increasing number of late-nineteenth century Americans, such life-cycle choices became increasingly complex. The family farm and the artisan shop gave way to work in large industrial enterprises. Compared to earlier generations’ experiences, work routines changed (Burnette 2021). Employment became less regular (Gordon 2016) but compensating differentials for unemployment risk were not fully compensatory (Fishback 1998, Averett, Bodenhorn and Staisiunas 2005). Workplace accidents became more debilitating; workers’ compensation replaced some (but not all) lost income and substituted in part for private precautionary saving (Kantor and Fishback 1996). Working lives were

\footnotetext{
${ }^{1}$ In economic parlance, saving is a flow variable, or an activity that occurs over time; savings is a stock variable, or the accumulated value at a given time of all past saving. Savings and wealth will be used interchangeably.
} 
shorter and age at peak productivity and earnings came earlier than they had on the family farm. A period of extended retirement in old age was not the norm (Ransom and Sutch 1986, Lee 2001). Rudimentary sickness and unemployment insurance helped fill income shortfalls and industrial life insurance protected families from loss of breadwinners, but insurance markets as life-cycle smoothing mechanisms were incomplete (Murray 2007, North 1979). Working-class households needed to make forward-looking choices to smooth consumption in the face of risky lifetime income, but rules of thumb passed down over generations in preindustrial economies were unhelpful in an unfamiliar urban, industrial economy.

This article offers some preliminary insights into the savings decisions of turn-of-thecentury households and contributes to an emerging literature on household saving choices in the nineteenth and early twentieth century. It analyzes savings account balances of working-class households between 1871 and 1911 at the Cornwall Savings Bank (hereafter CSB), which operated in Cornwall-on-Hudson, an upstate, New York village. Like many upstate towns, Cornwall experienced the economic transformations of the second industrial revolution, namely increased manufacturing employment and an expanding service sector.

Extant CSB ledgers provide complete histories of deposits, withdrawals and account balances of every depositor who opened an account over four decades. This study uses endof-year account balances for 341 depositors whose accounts were active for five years or more and could be linked to one or more federal decennial censuses and the New York State census of 1875 around the years accounts were open and active. Census links provide information on each account holder's age, sex, nativity, occupation, marital status, children in the household, literacy, and sometimes real estate wealth. Linked longitudinal data allow us to follow the saving decisions over several years, which is crucial to understanding life- 
cycle choices. Most previous studies of household wealth accumulation rely on crosssectional census data, so that inferences about life-cycle choices turn on assumptions about economic circumstances faced by different cohorts.

The focus here is life cycle saving. In its simplest formulation, Modigliani and Brumberg's (1954) life cycle hypothesis predicts a hump-shaped wealth-at-age profile: individuals (or households) accumulate wealth during their working years that they draw down in retirement. Evidence from the CSB records provides mixed evidence in support of the hypothesis. Most accounts were opened before age 40 and were closed after age 50. The full-sample results point to rapid accumulations from small initial deposits in account holders' twenties. Accumulation slows during savers' thirties, after which account balances grow through savers' early sixties. Average account balances at age sixty are equal in value to about one year's income. There is some evidence of a gradual drawing down of wealth after age seventy, and limited evidence of a bequest motive that might slow decumulation at older ages. The observed slower than expected decumulation in old age, however, may result from selective wealth-based attrition from the sample. If wealthier people live longer, predicted wealth after age 60 may not decline in the way predicted by the life cycle hypothesis as low-wealth savers exit the sample earlier than high-wealth savers.

When the data are parsed by sex, occupation, and nativity some differences in savings decisions become evident. The savings of men and women follow different trajectories that may be due to differences in household compositions. Female savers have fewer children present than male savers during the principal child-bearing and rearing years, but female savers have more children present after age sixty, which affects life cycle saving choices. Low-skill workers choices are more consistent with the hump-shaped prediction of the life 
cycle hypothesis than are those of white-collar workers. Moreover, low-skill workers exhibit higher peak savings than skilled workers, which is consistent with low-skill workers being less diversified and holding less non-bank wealth than skilled workers. Finally, the life cycle bank wealth of native- and foreign-born savings follow distinct trajectories, with foreign-born savers’ wealth-at-age exhibiting a more pronounced hump shape than that of native-born savers.

It is important to keep in mind throughout which wealth is observed and which is not. Because there were few other formal financial institutions readily accessible to Cornwall residents, it is reasonable to think that the CSB records capture most of the financial savings of the bank's depositors. Stocks and bonds were not widely owned prior to First World War bond drives (Ott 2011). Cornwall was without a building and loan, though building and loan mutuals in nearby towns allowed any Orange County resident to join (New York Superintendent of Banks 1893, New York Superintendent of Banks 1911, Price and Walter 2019). Cornwall was also without a benevolent society that offered sickness or unemployment insurance. Industrial life insurance became increasingly popular in the early twentieth century, and it is likely that at least some CSB savers owned life insurance but there is no way to identify them. Moreover, we do not observe traditional, informal consumption smoothing practices - borrowing and lending among networks of family and friends, peer-to-peer lending, merchant credit, private mortgage borrowing and lending, and so on. We do not observe life-cycle accumulations and decumulations of land, structures, and consumer durables. But if Sutch (2010) is correct in his contention that it was in this era that household's retirement portfolios transitioned from land and children to bank accounts, 
then savings banks' records will shed light on an important facet of households' life-cycle choices.

This paper contributes to a nascent micro-level literature on early savings banks. Extant household-level studies of United States savings banks have focused on New York City’s Emigrant Industrial Savings Bank (EISB), which was established in 1850 to serve Irish immigrants, and the Philadelphia Savings Fund Society, which was one of the country's earliest and largest savings banks. Few such studies address, even indirectly, financial accumulation over the life cycle. Kelly and ÓGráda (2000) and ÓGráda and White (2003), for example, use EISB depositor records to test information-based theories of depositor behavior during financial crises. ${ }^{2}$ Anbinder (2012) finds that Irish immigrants with EISB accounts accumulated substantial savings and achieved unexpected levels of financial stability, given that they were effectively economic refugees. He speculates, but does not show, that immigrant savings were mostly precautionary. Using EISB account transaction data, Wegge, Anbinder and ÓGráda (2017) and Anbinder, ÓGráda, and Wegge (2019) observe a wide range of saving behaviors: active accounts; large initial deposits followed by withdrawals of semi-annual interest payments; and gradual accumulation of balances that are withdrawn and the account closed. Wadhwani's (2002) analysis of immigrant accounts at the Philadelphia Savings Fund Society reveals that many foreign-born savers followed a target savings strategy in that they built up substantial balances then made a large withdrawal to close the account. None of these studies investigate life-cycle choices.

Male-headed households at the EISB had an average account balance equal to about six months’ wages. Comparable behaviors are observed at the CSB. At age 40 male-headed

2 ÓGráda (2009) and Ross (2013) study savers’ behaviors during panics in nineteenth-century Ireland and Scotland. 
households at the CSB, too, had an average account balance equal to six month's wages for industrial workers. Average peak savings at the CSB, which households achieved about ten years later, was equal to about one year's wages. The CSB data show less evidence of similar target savings strategies, but no formal test is offered here.

Two historical studies closest in spirit to mine are Alter, Goldin, and Rotella (1994) and Perriton and Henderson (2020). Perriton and Henderson study 195 accounts opened in 1830 at a London savings bank and track them to the accounts' closing. They, too, find evidence of three principal saving strategies: multiple deposits followed by a large lump-sum withdrawal; a large initial deposit that is depleted by multiple withdrawals; and active accounts that exhibit multiple deposits and withdrawals without apparent trend. The evidence points to "short-term accumulation, long gaps between deposits, and a distinct lack of success in the long term" (Perriton and Henderson 2020, p.33). They conclude that the results cast doubt on the life cycle hypothesis. Alter, Goldin, and Rotella (1994), on the other hand, follow 2,374 accounts opened at the Philadelphia Savings Fund Society in 1850. Men exhibit mostly target-type savings patterns; women, especially single women, were more likely to amass substantial nest eggs that were depleted in old age. The CSB data provide some evidence that the life cycle savings of women exhibit classic life-cycle patterns, as do the savings of immigrants.

\section{Theory and evidence on household saving in the Second Industrial Revolution}

Nineteenth- and early twentieth-century approaches to household savings

The motivations to save and the nature of household saving have engaged economists nearly from the beginning of economics (Smith [1776]1909, p.277). Alfred Marshall and 
Mary Paley Marshall (1879, p.41) group the different motivations for saving advanced up to the late 1870s into four broad categories: Intellect, Sympathy, Commercial Security, and Interest Rates. By Intellect, the Marshalls (1879, p.37) mean that the "inclination to save arises from the hope of future advantage.” In modern terminology this can be interpreted that people are forward looking and save when an extra dollar of future consumption is preferred to an extra dollar of current consumption. Sympathy, to the Marshalls (1879, p.38) is other-regarding behavior, in that "there is more wealth saved for the sake of others than for the future enjoyment of those who save it.” People whose preferences are interdependent save to ensure the consumption of others if the principal breadwinner falls on hard times or to leave bequests to support family members after the savers’ deaths.

Commercial Security implies that the saver "hopes that he and his family may enjoy in security the fruits of his savings" protected by and from the government (Marshall and Marshall 1879, p.38-39). That is, people will save when bankers can be trusted, and the state's capacity to expropriate its citizens' wealth is limited. For the Marshalls, English savings banks and friendly societies, established in the first industrial revolution for the benefit of the poor, took on greater importance in the second industrial revolution through the assurances that savings banks offered working-class depositors. Nineteenth-century prudential regulation - limited bank risk taking, protection of principal, and light taxation increased savers' confidence that their private capitals were secure. Americans followed the British lead in chartering savings banks subject to similar regulations. High Interest Rates will stimulate saving, of course, but the Marshalls (1879, p.41) understood that people have different preferences in that "a man's temperament" more than the rate of interest will determine "whether he makes provision for his old age and for his family." That is, forward- 
looking, life-cycle saving was interest inelastic, a feature Friedman (1957) incorporated into his permanent income hypothesis.

Modern approaches to saving build on these long-standing notions of risky future income and employment, private provision of financial security in old age and retirement, and concerns over financial security of family members. Boulding (1966, p.535), for example, noted that, all else equal, "a man with a safe job [will] save less than a man with an uncertain job.” Keynes (1936) labeled this response precautionary saving, which is a wealth buffer maintained so that future consumption will not fall below some desired level even if one or more members of the household experience a period of unemployment. Modern extensions of the precautionary savings hypothesis include Deaton’s (1991) and Carroll's (1997) buffer-stock approaches, which posit that impatient households have target wealth-to-income ratios. Whenever the ratio falls below the target, households delay consumption and save until the target ratio is reestablished. When the ratio rises above the target, impatient householders will consume out of current savings until the lower target ratio is reached.

One of the more studied models of savings is the permanent income-life cycle model. Friedman’s (1957) permanent income hypothesis challenges Keynes' notion that households focus on current income and consumption in making saving decisions. Rather, households consume (and, by implication save) in the present based on their expectations concerning incomes and preferred consumption over an infinite horizon. Household saving and dissaving in each period follows a long-term path determined by expected permanent income and interest rates. Deviations from that path follow from transitory income shocks. 
Modigliani’s (1986) life cycle hypothesis shares much with the permanent income hypothesis, though the life cycle hypothesis assumes a finite horizon and accounts for changes in family size and structure over the life cycle. A bequest motive too can be readily incorporated into the life cycle approach. One reason for the popularity of the life cycle hypothesis, surely, is that it yields a straightforward empirical implication, namely that the wealth-age profile will exhibit a hump shape which reaches a maximum at or near retirement age. Assets are accumulated over a household's working life and spent down in retirement.

Because it has been modified, qualified, and extended in various ways, the permanent income-life cycle approach maintains a prominent place in the economist's toolkit (King 1985, Shefrin and Thaler 1988, Cagetti 2003). One modification that informs studies of nineteenth-century saving is the life-cycle squeeze. Di Matteo (1998) and Lilja and Bäcklund (2013) argue that traditional households experience an early adulthood squeeze when children are too young to contribute to household income, and an old-age squeeze as household incomes decline with declines in productivity and wages (Haines 1979, Ransom and Sutch 1986). If we take seriously the assumptions of forward-looking decision making underlying the life cycle hypothesis, however, a genuine "squeeze" results from unanticipated additions to the family, perhaps having more than the planned or preferred number of surviving children, or unanticipated declines in later-life productivity due to worse than expected health or an unlikely but debilitating accident. Otherwise, observed deviations from a smooth long-term trend in wealth accumulation may be integral features of planned life cycle saving. People expect that the birth of children will affect their capacity to save and plan accordingly. 
This paper investigates whether a sample of small-town savers in upstate New York in the late nineteenth and early twentieth centuries saved in ways consistent with the most basic prediction of the life cycle hypothesis. The focus on life cycle behaviors is driven by the nature of the data collected to date, on the empirical demands placed on the data, and the long-standing concern among economic historians with historical patterns of wealth accumulation over the life cycle. The buffer stock and permanent income hypotheses demand some knowledge of each saver’s permanent and transitory incomes (Paxson 1992, Bodenhorn 2019), which is rarely available and estimating it is beyond the scope of this study. Thus, an investigation into the extent to which late nineteenth- and early twentiethcentury households accumulated financial assets in a fashion consistent with the life cycle hypothesis is an important first step toward understanding historical household choices. Because it is a robust, yet falsifiable hypothesis, it informs this study. It also accords with nineteenth-century writers', like the Marshalls', concerns with how households provided for themselves and their dependents in old age.

\section{Evidence from North America on wealth over the life cycle}

Table 1 summarizes 18 published studies that explore life cycle wealth accumulation in the second half of the nineteenth century. Fourteen use information drawn from the decennial federal censuses of 1850, 1860 and 1870 . One uses wealth data drawn from detailed microlevel state property taxes records from Massachusetts and Ohio. Three studies use probate records of Ontario decedents, who are linked to the Canada federal census of 1891. Apart from Sutch (2010), which uses a nationally representative sample of 47,000 heads of households available through the IPUMS project (Ruggles et al 2021), the records were hand 
collected. Given the costs of hand-collection, the samples sizes are modest, and the geographic coverage limited. Steckel (1990), Ferrie (1994), Gregson (1996), and Lee (2005) create panel data by linking individuals across censuses, though Ferrie's is the only study that exploits the panel structure. ${ }^{3}$

[Table 1 about here]

Papers listed in Panel A of Table 1 use wealth reported in the census manuscripts. Although the principal concern of some studies is wealth inequality, most discuss accumulation over the life cycle after reporting regressions of wealth on age. Summarizing the results as age at peak wealth fails to convey the richness of these studies but captures the essential life-cycle results. Each study estimates a quadratic in age in a wealth regression and each generates a hump-shaped wealth profile with an average age at peak wealth of 54.8 years, excluding the implausible age-at-peak wealth value calculated from coefficients reported by Ferrie (1994). The strictly urban samples used in Conley and Galenson (1994) and Herscovici (1998) imply younger ages at peak wealth (49 years) than all-rural samples (62 years) used by Atack and Bateman (1981), which is consistent with farm households' greater fraction of real-to-total wealth and the slow climb up the agricultural ladder from farm labor to fee simple ownership.

Evidence from property tax and probate records is also consistent with Modigliani’s life cycle hypothesis. Steckel (1994) links 1,174 Massachusetts and 1,171 Ohio property tax records from 1850 to the federal census of that year. The data generate the standard humpshaped wealth-age profile consistent with Modigliani’s hypothesis, but additional regressors

\footnotetext{
${ }^{3}$ Bleakley, Cain and Ferrie (2015), Bleakley and Ferrie (2016), and Collins and Zimran (2019) regress census wealth on age but do not report parameter estimates because life-cycle choices are not the authors' principal concern.
} 
included in the estimating equations complicate the interpretation of the age coefficients. Di Matteo (1997) reports evidence consistent with the hump-shaped wealth-age profile predicted by the life cycle hypothesis. In a subsequent paper, he estimates the wealth-age profile using nonparametric LOWESS procedure and identifies two periods in which the wealth-age profile flattens, namely the decedents' late twenties to mid-thirties and again in the late forties and early fifties. Di Matteo (1998) argues that these two periods of a flattening of the curve is consistent with the ages at which we expect to observe life-cycle squeezes.

A notable feature of the studies summarized in Table 1 is the outpouring of wealth studies published in the 1990s and early 2000s and the few published afterwards. One reason, surely, is that, although censuses are valuable historical resources, researchers quickly grasped the many limitations of census-reported wealth. First, the 1850 census, for example, provides only the value of each household's real estate (land plus structures). The 1860 and 1870 censuses report real and personal estate; the latter was supposed to include the value of all household goods, livestock, financial assets and so forth. Despite the Census Office's intention to include all types of wealth, reported values of personal property were implausibly low or simply missing altogether (Galenson 1991).

Tax and probate records do not resolve the fundamental inferential issues that arise in the use of census data. One advantage of probate records is that courts collected a lot of information on the characteristics of the decedent's households, including the age of the decedent, marital status, ages of children living in the household, as well as all known assets and debts at the time of death. But, in addition to the challenges involved in inferring lifecycle choices from census date, a further disadvantage of probate records is that they include only a subset of all deceased householders, which may not be representative of the 
population. Decedents are older than the overall population. Age-specific mortality weights can correct for nonrepresentative age distributions to the extent that published mortality estimates capture the true experience of the sample at hand. Moreover, the estates of poor or unmarried decedents are often not probated (Lilja and Bäcklund 2013). And, like census data, the probated values of a decedent's nonfinancial assets were not market values; they were estimates provided by executors or others assigned by the courts to assess the estates.

Given the inferential issues that beset census, tax, and probate sources, subsequent studies of household consumption-smoothing and savings behaviors have turned to historical surveys (Scott and Walker 2012, Bodenhorn 2019), long panels of governmental or administrative documents (Guinnane and Streb 2011), pensioner accounts and their private savings (Bourdieu, Kesztenbaum, and Postel-Vinay 2011), and savings bank accounts (Alter, Goldin and Rotella 1994, Wadhwani 2002, Anbinder, ÓGráda and Wegge 2019). This study follows the last strategy in that it makes use of a novel dataset drawn from the records of a small-town, turn-of-the-century New York savings bank to investigate household accumulation of financial wealth.

\section{Background}

Scholars should proceed with caution when pouring historical data into modern theoretical bottles. The life cycle hypothesis as widely understood may reasonably capture the behavior of a particular twentieth-century demographic of interest to Modigliani (1986) - white, educated, urban, middle-class - but it may not capture the choices of other peoples in other places and other times (Wolff 1981). It is incumbent on the historian then not to invoke the hypothesis uncritically. The Marshalls' (1879) belief that nineteenth-century 
households were forward looking and concerned with providing for themselves and others in their old age, however, suggests that a life cycle approach might illuminate the nineteenthcentury experience. But before turning to the data, it will be useful to discuss several features of the turn-of-the-century economy that inform any interpretation of the results.

Working years, old age, and the nineteenth-century life cycle

Three trends transformed the U.S. economy in the second half of the nineteenth century, each of which would have led households to change how they saved to support themselves in old age. First, urbanization and industrialization pulled an increasing share of the population off the family farm. Davis and Gallman (1978) show that investment in land and structures constituted the largest share of investment up to the Civil War. For most households, the family farm was the principal asset in the retirement portfolio, and one used to finance consumption in old age, either through lease, sale or an inter vivos transfer to one or more children who agreed to support aged parents. Second, declining fertility meant that there were fewer children available to support elderly parents. Third, the emergence of an array of financial institutions widened access to alternative forms of saving. Such institutions included savings banks, life insurance companies, and various beneficial societies. The emergence of formal financial intermediaries replaced informal mechanisms of consumption smoothing, such as peer lending, merchant credit, or holding wealth embodied in physical assets, such as land, livestock, specie, and durables (Deneweth, Glederblom and Jonker 2014). This confluence of changes in employment, residence, demographics, and finance led Sutch (2010, p.4) to assert that turn-of-the-century U.S. households increasingly "substituted bank accounts for babies" in their retirement portfolios. 
Moreover, thinking about the life cycle in the late nineteenth century requires, if not a redefinition, a reformulation of the notion of "retirement." In the twenty-first century, retirement often implies an abrupt transition from the workaday world to an extended period of leisure and tending to one's gradually deteriorating health. Few sixty-year-old men and women in the late nineteenth century conceived of old age in such terms. From information reported in the decennial censuses, Lee (2001) estimates expected years of retirement at age 20 by cohort. A young man who entered the labor market at age 20 in 1850, for example, had a remaining life expectancy between 38 and 44 years, only 2 to 3 years of which would be spent in retirement. By comparison, a twenty-year-old who entered the labor market in 1990 anticipates 12 to 16 years of life in retirement.

A fundamental assumption of the life cycle hypothesis is that individuals form accurate forecasts of their life courses, so workingmen's beliefs about their expected working life should be reflected in observed choices. There is not much evidence bearing on latenineteenth-century workers' expectations, other than a survey by the New Jersey Bureau of Statistics of Labor and Industry (1889) of more than 600 individuals employed in several industries. The Bureau asked a series of questions about the ages at which men started work in their occupations, the age at which productivity started to decline, the age at which they could no longer work at their current occupation, and the life expectancy of men employed in their jobs. Table 2, which summarizes their responses, shows that young men entered their occupations around age 16 . Workers anticipated the onset of productivity decline at age 42 and an inability to work in their current jobs at age 57. They expected to live, on average, until age 66. These men's expectations are remarkably consistent with Lee's (2001) estimates of life expectancy at age 20 in 1890 (41 to 46 years) and working life (38 to 41 
years). Late-nineteenth century workers formed reasonably accurate forecasts given the information available at the time.

[Table 2 about here]

The decade between incapacity to work in the occupation taken up in youth and death was not a period of extended leisure, however. It was a period of working in less taxing jobs and extended spells of under- and unemployment (Margo 1993, Lee 2003). Based on the New Jersey and other surveys, Ransom and Sutch (1986) and Sutch (2010) find that retirement was more a phasing-out process after age 55 than abrupt shift into leisure. We might then observe continued wealth accumulation into ages at which a retiree, in the modern sense of the term, would be drawing down their wealth because they may not have fully exited the labor market (Hurd 1987).

\section{Cornwall Savings Bank}

The Cornwall Savings Bank, from which the data (discussed in greater detail below) used in this study comes, was established in 1871. The bank's first president, William T. Cocks, was a merchant and partner in a carriage manufactory; its first treasurer was a milk dealer. The bank's founding trustees included an attorney, a coal merchant, a druggist, a boatman, a livery owner, and two farmers (New York Superintendent of Banks 1887). In other words, the bank's directors reflected the distribution of occupations, skills, and incomes of the local community. Prior to the CSB's opening, the nearest banks of any kind were the Bank of Newburgh, a commercial bank five miles from Cornwall, and the Bank of Orange County, a commercial bank in Goshen about 17 miles away. As commercial banks, neither would have encouraged or even accepted small personal savings accounts. Other than 
the CSB, there were few organizations that offered residents contact with a formal financial institution in the 1870s. Cornwall residents might have purchased life or fire insurance through one of a dozen agents in Newburgh or from one of five agents in Goshen; they might have joined the lone benevolent society in Newburgh, but sickness and employment societies, which were subject to moral hazard, preferred local members who were readily monitored (Murray 2007). They may have joined a building and loan to finance a house purchase, but these too tended to prefer local members. In short, if a Cornwall resident wanted to engage with a modern financial institution on a regular basis, the CSB was his or her principal option.

The CSB was in the village of Cornwall-on-Hudson, which was within the town of Cornwall in Orange County, New York. Cornwall is located on the Hudson River about midway between New York City and Albany. In 1870 Cornwall had nearly 6,000 residents; 76\% were native born, 98\% were white. Like all late nineteenth-century towns, Cornwall supported several blacksmiths and butchers, tailors and milliners, confectioners and grocers. The town was home to some light industry, including a woolen carpet mill, a carriage manufactory, a flour mill, a planing mill (doors and window sashes), and a brick machine manufactory. Cornwall was best known as a summer vacation destination, however. There were several large, modern hotels that served travelers and tourists between May and November. An 1878 advertisement for the Glen Ridge House, for example, described a hotel that could accommodate 250 guests. It featured all modern conveniences including gas lighting, hot running water, and spring beds, and it was a convenient coach ride from the steamboat landing and the Hudson River Railroad depot (Lawrence 1878, p.118).

[Figure 1 about here] 
Any case study faces the issue of representativeness. What is currently known about savings bank depositor behavior is based on data from the Philadelphia Saving Fund Society and the Emigrant Industrial Saving Bank. The Philadelphia bank is one of the oldest and largest savings banks in the United States. The EISB, too, is not only one of the country's largest banks operating in its largest city, but the bank initially served Irish famine immigrants. Thus, neither tells us much about choices outside large urban areas. Figure 1 plots the rank-size distributions of all of New York’s savings banks in 1889 in four relevant dimensions: total deposits, total number of depositors, average account balance, and the population of the town each bank served. The CSB's place in each distribution is designated with a black diamond. For comparative purposes, the EISB's place is designated by a black square. It is readily apparent that the CSB is one of New York's smallest savings banks. It is the smallest bank by deposits, third smallest by depositors, fifth smallest by average account size and operated in the eleventh smallest market with a savings bank. The CSB in 1889 held just 5.1\% of the median bank’s total deposits, it had $11.7 \%$ of the median bank's depositors, and $45.8 \%$ of the median bank's average account balance. Its depositor base, as discussed below, was diverse when measured by age, sex, nativity, and occupation. It is safe to say no more, however, than that the CSB is comparable to other small-town savings banks.

\section{Data}

Any empirical study of household savings and wealth accumulation over savers' lives faces formidable data challenges, some of which were addressed in the discussion relative to Table 1 . The ideal data would include long-term, longitudinal, individual- or household- 
level information on a large, representative sample of households that contains information on the portfolios of each household. The CSB data exhibit three desirable features: they span (potentially) long periods; matching savers to federal or state censuses provides information on household characteristics; and, because the principal data are bank account balances kept in the bank's ledgers, the wealth data should be reasonably free of systematic reporting error. The data do not capture the totality of households' assets. We do not observe any information on the accumulation of consumer durables, real estate, cash other than CSB deposits, or other non-bank financial assets. But lacking ready access to other formal financial institutions, account balances at the CSB should capture most of these households' financial wealth.

Data are drawn from the bank’s first two deposit ledgers, which include accounts opened between July 1871, when the bank opened, to January 1911. Depositors enter the ledgers in the chronological order of date of initial deposit. Account \#1 was opened by Frederick Dezendorf, a married 29-year old carpenter with four children between 3 and 17 years old, and continue through account \#4296, which was opened with a \$5 deposit in the name of Christina L. King, a six month-old girl, presumably by her father, a 35-year old machinist who lived in nearby Woodbury, New York. The first ledger takes the standard nineteenthcentury form with debits (withdrawals) recorded in the left-hand column and credits (deposits and interest earned on balances) in the right-hand column. Accounts were balanced and interest credited on January 1 and July 1 of each year. The second ledger has separate pre-printed columns for date, withdrawals, deposits, interest earned, and account balances.

Given the nature of the raw data, the sample is constructed on three criteria. First, it includes accounts that remained open for at least five years because any study of life cycle, buffer stock, or precautionary choices turns on observing changes in accounts over an 
extended period. Of 2,064 accounts surveyed, 578 or $28 \%$ were opened by individuals and active for at least five years. ${ }^{4}$ The five-year requirement introduces meaningful selection bias and inferential problems regarding life-cycle choices if accounts that meet the fiveyear criterion differ in a systematic way from, say, accounts that remained open for at least four or six years, which seems unlikely. Accounts open for several years surely differ from accounts open for a few days or months, however. But short-lived accounts are unlikely to have been opened for life cycle, precautionary, or target savings purposes.

Second, the individual named in the account ledgers must appear in and be matched to one or more of manuscript censuses: the federal decennial censuses of 1870, 1880, or 1890, or the New York State census of $1875 .{ }^{5}$ Matching was done by hand using given and family names. If more than one individual had the same name as the depositor and was resident in Cornwall or a neighboring town, the depositor was not matched. Matching to the censuses was not restricted to Cornwall, but most of the matched depositors lived in Cornwall or a neighboring town in Orange County, New York. Of the 578 accounts open for at least five years and eligible to match, 341 or $59 \%$ were successfully matched. Matches are not always exact, given the loose spelling conventions of the era, but a conservative matching procedure is adopted because Bailey et al (2020) and Anbinder et al (2021) argue that false negatives (no match) create fewer inferential biases than do false positives (wrong match).

Third, the account holder named in the deposit ledger must be at least 20 years old. The ledgers include hundreds of accounts opened by parents and trustees on behalf of minor children. Accounts opened during childhood that did not remain open and active for at least

\footnotetext{
${ }^{4}$ Organizations included a local chapter of the Grand Army of the Republic, the local library, two churches, and the Odd Fellows, among others.

${ }^{5}$ The individual-level records of the 1890 federal census were destroyed and transcriptions of the New York State census of 1892 are incomplete.
} 
five years beyond the individual's twentieth birthday are excluded from the sample. For accounts opened prior to age 20, the analysis is restricted to the account holders' post-20year choices.

[Table 3 about here]

The resulting sample is an unbalanced panel of 341 individual account holders observed between 5 and 41 years between 1872 and 1911. There are 4,651 depositor-year observations. The average account holder is observed for 13 years. The sample is about equally divided between male- and female-headed households. Table 3 reports the summary statistics. Panel A reports statistics that evolve over the life cycle, namely account balances or financial wealth-at-age, account holder's age, spouse's age if married, and the number of children in the account holder's household. The average account balance in real terms is \$290.93; male-headed households’ average real balance was about $\$ 40$ greater than female headed households' average balance, but the difference is not statistically significant $(\mathrm{t}=1.00) .{ }^{6}$ Nominal balances are converted to real values using the David-Solar price index (Carter et al 2006, Series Cc2). ${ }^{7}$ The average age of all account holders is nearly 47 years,

\footnotetext{
${ }^{6}$ Of the 181 female account holders, 108 were unmarried women. It is impossible to determine from the sources whether they were widowed, abandoned, or never married. Approximately 90 percent of unmarried females' households reported no children present, which is the only meaningful difference between married and unmarried women: there is no statistical difference in average account balances or age, so married and unmarried women are analyzed together throughout. Alter, Goldin, and Rotella (1994) find some differences between married and unmarried women. The sample used here includes about 10 percent as many female account holders as their sample, which allows them to analyze the two groups separately.

${ }^{7}$ Deflating deposits by three alternative price indices, namely All commodities (Series Cc125); All commodities other than farm products (Series Cc126); and Food Prices (Series Cc128) does not alter the principal results (Carter et al 2006). Using nominal values also does not change the results in a meaningful way. See the Online Appendix. It is important to convert nominal deposits to real values because the overall price level falls by one-half from the end of the Civil War to 1896, followed by an inflation that leads to a cumulative price increase of $45 \%$ up to 1911 . The real returns on pre-1896 savings were positive beyond the $4 \%$ interest paid by the bank on deposits. Real returns were lower than the nominal $4 \%$ interest on deposits. The results also do not differ in a meaningful way if the sample is trimmed of the largest $5 \%$ of accounts by dollar value.
} 
with no meaningful difference between male and female account holders. Women's spouses were more than seven years older than men's spouses, which is a statistically significant difference ( $\mathrm{t}=12.29)$. Male account holders' households include more children and are less likely to have no children present.

[Figure 2 about here]

Panel B reports some features of the life-cycle nature of the CSB's depositors' accounts. The average age at initial deposit is 41 years for both male and female account holders. The average age at the final withdrawal that closes the account occurs at age $50 .{ }^{8}$ Figure 2 provides histograms of age at opening and age at closing. The figure reveals that depositors opened accounts at every age between 20 and 80; they closed accounts at every age between 20 and 90 . The distribution of age at opening is right skewed, in that median age at opening (31 years) is less than the average age. The distribution of age at closing is more symmetrical in that the median age (50 years) is nearly equal to the mean age (49.6 years).

The average initial deposit is $\$ 145$ and the average final withdrawal to close an account is $\$ 324$. Both distributions demonstrate a pronounced right skew due to a few very large deposits and withdrawals. The median opening deposit is $\$ 67$. The median closing balance is $\$ 84$. Viewing these values along with the mean and median age at maximum account balance provides some preliminary insights into the life-cycle pattern of savings. Age at maximum balance is about halfway between age at account opening and closing. The average maximum account balance is nearly $\$ 600$. The net addition to the average account

\footnotetext{
${ }^{8}$ Closed accounts can be distinguished from inactive accounts with a zero balance because the bank's clerks usually drew a red diagonal line through closed accounts. In a few other instances, the clerk recorded that the depositor's savings book was returned. Three accounts remained open despite a withdrawal leaving a zero balance. These three accounts exhibited subsequent deposit and withdrawal activity.
} 
between initial deposit and peak account balance is $\$ 475$. The net decumulation between peak balance and final account-closing withdrawal (exclusive of the final withdrawal) is $\$ 223$.

The median account-closing withdrawal at 40 years is $\$ 135$; it is $\$ 345$ at 50; $\$ 111$ at 60; and \$164 at 70. Except perhaps for fifty-year-old depositors, final withdrawals are not indicative of the target-savings strategies observed at the Philadelphia Saving Fund Society (Alter, Goldin, and Rotella 1994). Final withdrawals are less than one-half of annual average income. They are generally less than $5 \%$ of the average real values of real estate $(\$ 3,889)$ and personal estate $(\$ 3,157)$ held by depositors reporting real estate or personal estate in the 1870 federal census. They are less than $7 \%$ of the average real value of the depositor's house $(\$ 2,571)$ occupied by depositors reporting a house value in the 1875 New York state census. Based on the relatively large amounts withdrawn when accounts were closed at the PSFS, Alter, Goldin and Rotella (1994) believe that some Philadelphia depositors saved to purchase real estate or to buy into a business. The modest values of account-closing withdrawals among the CSB's depositors are not consistent with large purchases after closing accounts. Given the advanced age of some holders of closed accounts, the account-closing withdrawals may have occurred following the depositors' deaths and served as bequests. But the modest amounts associated with account closing is not evidence of a strong bequest motive. Bequests of $\$ 100$ or less when average household income exceeded $\$ 500$ was not enough to guarantee an heir or dependent's consumption for more than a few months.

\section{Empirical approach}


Estimates of the effects of age on wealth follow the standard individual fixed effects approach (Angrist and Pischke 2009). The estimated equation takes one of two forms: (1) one in which each age between 20 and 80 enters as a fixed effect; and (2) one in which age enters as a quadratic. The fixed effects equation takes the following form:

$$
w_{i k j t}=\alpha_{i}+\sum_{t=1}^{2} \theta_{t} I\left(\operatorname{Era}_{t}\right)+\sum_{k=20}^{80} \gamma_{k} I\left(\text { Age }_{i k t}\right)+\sum_{j=1}^{6} \beta_{j} I\left(\text { Children }_{i k j t}\right)+\varepsilon_{i k j t}
$$

The quadratic equation takes the following form:

$$
w_{i j t}=\alpha_{i}+\sum_{t=1}^{2} \theta_{t} I\left(\operatorname{Era}_{t}\right)+\gamma_{1} \text { Age }_{i t}+\gamma_{2} A g e_{i t}^{2}+\sum_{j=1}^{6} \beta_{j} I\left(\text { Children }_{i j t}\right)+\varepsilon_{i t},
$$

where $\mathrm{w}_{\mathrm{ijt}}$ is the real value of each individual's savings account balance on 1 January of year t; $\alpha_{\mathrm{i}}$ are individual fixed effects that capture unobserved, time-invariant factors, which may include permanent income, long-term interest rates, time preferences and so on; $I\left(E^{2} a_{t}\right)$ are era fixed effects that capture three periods of increasing economic growth as well as three recessions that shock individual incomes and presumably wealth; I(Age $\mathrm{ikt}_{\text {t }}$ is a vector of individual-level, time-varying indicator variables that take a value of one for each age at which the individual is observed and zero otherwise; I(Children) ${ }_{\mathrm{ijt}}$ is a vector of individuallevel, time-varying indicator variables that take value of one for each of six variables that signify between one and six or more children present in household $i$ at time $t$ and zero otherwise; the reference category is zero children in the household; $\varepsilon_{\text {it }}$ is the error term. In the second equation Age enters as a quadratic rather than as a series of fixed effects. 
Preliminary regressions using a cubic and a quartic in age generate similar results, so the reported results are limited to the quadratic specification. The estimated coefficients on age are the principal coefficients of interest.

The identifying assumption underlying fixed effects models is that correlation between unobservable factors that might simultaneously affect the dependent variable and one or more of the independent variables are time-invariant. Identification precludes the inclusion of year and age fixed effects. If age and year fixed effects are included in addition to the individual fixed effects, the coefficients will not be identified due to the so-called age-period-cohort problem (Heckman and Robb 2012). The individual fixed effects will include, among other factors, the savers' birth years so that a component of the fixed effect will be a linear combination of the age and year effects (i.e., age = year - birthyear). This linear dependency can be broken if it is possible to substitute a theoretically plausible variable that substitutes for yet captures a relevant feature of any of the three linearly dependent variables (Mason and Wolfinger 2001). One possibility in the present context is to replace the year variable with several cohorts that may have come of age in periods that experienced different rates of economic growth. If a cohort expects to live and work through a period of accelerating real wage growth, for example, its members may save less early in their working careers, which shifts consumption forward and equates the expected per period marginal utility of consumption over time. One consequence of anticipated real wage growth is that these later cohorts will be expected to save less earlier in life and more later.

Thus, the regressions do not include individual year fixed effects. Rather, Romer’s (1989) revised gross domestic product figures and Davis’s (2004) industrial production index are used to identify three distinct regimes of accelerating economic growth in the 
economic time series. Each series, constructed independently, point to three regimes: 1871 to 1879 (slow growth), 1880 to 1894 (gradually accelerating growth), and 1895 to 1911 (rapid growth). See Online Appendix Figures A1 and A2, which plots the time series, and the trend growth rates of each. The regressions include indicator variables for the two later periods. The data also reveal three recession years, namely, 1885, 1893, and 1908. A recession indicator variable is also included in the regressions to capture any short-run savings responses to unanticipated declines in economic activity or real wages.

Identification also requires repeated observations and variation in the right-hand side variables. If these conditions are satisfied, the coefficient of interest, $\gamma$, will provide unbiased estimates of the effects of age on wealth. Are these identifying assumptions satisfied? Theory itself presupposes that most of the unobservable factors that will influence wealth accumulation - permanent income, time preference, education, experience, long-run interest rates - are fixed over the life cycle. In terms of the key right-hand side variables, there is substantial within-individual variance. The mean age is 46.9 years with a within-individual standard deviation of 5.9 years, or $12.6 \%$ of the mean. ${ }^{9}$ The mean number of children in the household is 0.96 with a within-individual standard deviation of 0.60 children, or $62.5 \%$ of the mean.

\section{Results: Evidence on the life cycle hypothesis among turn-of-the-century savers}

\footnotetext{
${ }^{9}$ There is some evidence of age heaping in the censuses. A larger fraction of respondents reported ages ending in zero and five than might be expected. Age heaping introduces attenuation bias on regression estimates of age effects. The most significant heaping occurs on ages ending in zero, but the excess zeroes are nearly offset by shortfalls in ages ending in one and nine, so the reporting errors appear to be small. See Online Appendix Figure A5 and Table A4 for details.
} 
This section presents results on the life-cycle savings patterns of Cornwall Savings Bank depositors. A discussion of relevant subsamples appears after a discussion of the full-sample results. The coefficient estimates are reported in the Online Appendix. The discussion here relies on graphs derived from the regression estimates.

\section{Full-sample results}

[Figure 4 near here]

Figure 4 provides a graphical representation of the life-cycle accumulation of financial wealth among the CSB's depositors, based on the coefficients estimated using Equations 1 and 2 (see Online Appendix Table A1 for estimated coefficients). The black diamonds represent the point estimates on each age between 20 and 80 years from the regression of real account balances on age fixed effects. The vertical gray bars represent the 95\% confidence intervals around the point estimates. The solid curve represents a smoothed representation of the predicted value of depositor financial wealth at each age based on a regression of account balances on a quadratic in age like that in Equation 2. Standard errors are clustered on the individual depositor. All regressions include controls for eras, recessions, and number of children residing in the household at each depositor's age.

The figure offers a portrait of steady accumulation over the CSB's depositors' lives. At 20 years, the average depositor has less than $\$ 20$ in his or her account. At age 30 the estimated average account balance is $\$ 221$; at age 40 the average account balance is $\$ 320$; at age 50 it has increased to $\$ 403$; at age 60 the average account balance is $\$ 572$, which is about equal to annual average real wages in the United States in 1890, the midpoint of the sample period (Carter et al 2006, Series Ba4280, Cc2). The unexpected feature that appears 
in the figure is the steady increase in estimated wealth up to age 75 after which it turns down. That is, the hump-shape predicted by Modigliani’s (1986) life cycle hypothesis appears only at advanced ages by turn-of-the-century standards: Lee’s (2001) estimate of life expectancy for the cohorts born in 1850 is 64 years with an expected working life of 61 years. It should be noted, as well, that the standard error bars widen after age 60 because the point estimates are derived from an ever-decreasing number of observations. If the likelihood of sample attrition is negatively correlated with wealth, so that wealthier individuals live longer, the upward trend after age sixty may be an artifact of negative selection on wealth into mortality.

If the estimated late-age pattern is the true pattern, however, it raises the same questions surrounding the life-cycle pattern of gradual accumulation with little or no decumulation after retirement that also arise in modern studies. One explanation for the failure to draw down savings is uncertain mortality risk. People cannot predict the exact date of their demise. A second explanation holds that because there is a maximum age to which people expect to live and, absent a strong bequest motive, people will want to consume all their wealth by that age (Kotlikoff and Spivak 1981, Danziger 1982). ${ }^{10}$ The failure of elderly savers to consume all their wealth as they age then implies a strong bequest motive. Hurd (1987) proposes a simple test for a bequest motive. Under a strict life cycle hypothesis without a bequest motive, the elderly will dissave as they age due to rising conditional mortality probabilities. But savers with a bequest motive - other-regarding individuals' whose

\footnotetext{
${ }^{10}$ More recent studies include Davidoff, Brown and Diamond (2005) and Lockwood (2012) in which the authors argue that people increase lifetime utility if they annuitize all wealth that they do not plan to bequeath. In the absence of annuities, which were not widely available at the turn of the last century, savers may build up a potential bequest, but then effectively purchase a life annuity from their heirs by spending down the annuity if they live longer than expected.
} 
utilities increase in their heirs' well-being — are less likely to draw down their wealth. Rather, they prefer to leave wealth behind for their heirs.

De Nardi et al (2021) offer a variation on the Hurd (1987) test. Households made up of couples continue to save, or at least not dissave, in older ages until the death of one spouse. Wealth is drawn down in a fashion consistent with Modigliani’s life cycle hypothesis only after a spouse's death. Single, divorced, or widowed individuals spend down their savings in old age. De Nardi et al (2021) attribute these alternative dissaving patterns to the tendency among married couples to distribute most of a deceased spouse's bequest to the surviving spouse, with perhaps lesser bequests left to non-spousal heirs. Both the Hurd (1987) and De Nardi et al (2021) hypotheses yield straightforward prediction concerning dissaving in old age that can be tested here: savers with spouses or savers with children will draw down wealth in old age less quickly than never married savers or those that never had children.

Information from the CSB and linked to the censuses does not allow us to observe whether individuals have surviving children or spouses, but we can observe whether a depositor ever reported children or spouses present in their households. Children ever present and spouses ever present are imperfect measures for the true variables of interest, but they should be correlated. Using these proxy measures also provides some tentative insights into whether dissaving is driven by mortality risk or other-regarding behavior.

My test of the Hurd (1987) and De Nardi et al (2021) differs from theirs in another respect. Rather than looking for correlations between gradual dissaving at older ages and children or spouses, I look for correlations between the elapsed time between age 50 and the closing of a saver's account using standard survival analysis. I assume that accounts closed at older ages are likely to have been closed near or after a saver's death. Clerks at the CSB 
noted that accounts were closed by executors in only a handful of cases, but 88 accounts (25.8\% of the sample accounts) were closed between age 50 and 80 . Given life expectancies of about 60 , it is reasonable to think that many of these were closed around the time of the saver's death. It is possible that when elderly savers closed their accounts before death, they engaged in inter vivos transfers, but such transfers would effectively serve as bequests. If the typical saver had a strong bequest motive, we would expect to observe that the accounts of savers with children or spouses would be remain open longer as savers reduce current consumption to leave bequests for their heirs.

[Figure 5 near here]

Figure 5 presents Kaplan-Meier survival graphs, which plot the estimated time to account closing for savers 50 years or older. The left panel separates savers into those that report ever having children present and those not. One way to interpret the graphs is to look at the 0.50 value on the $y$-axis. If we trace a horizontal line from that point to the solid line and then drop the perpendicular to the x-axis, we see that the median saver age 50 or older who ever reported children in his or her household closed his or her account in about 10 years (or at age 60). If we do the same for the dashed line, we see that the median saver age 50 or older who did not report children in the household closed his or her account after about 18 years (or at age 68). Despite the apparent difference in the two lines, the p-value of the log-rank test for the equality of the survivor function is 0.44 . We cannot reject the null hypothesis that the time to account closing is the same for the two groups. Thus, it does not appear that savers' disinclination to draw down their account balances, or exhaust their savings and close their account, is driven by the greater likelihood that they have surviving children. 
The right panel traces the Kaplan-Meier curves for older savers with spouses and without spouses ever present. The time to closing the account of the median saver 50 years or older who ever reported a spouse present is about 12 years. The time to closing the account of the median saver 50 years or older who did not report a spouse present is nearly 20 years. The $\mathrm{p}$-value of the log-rank test for equality of the survivor functions in 0.10 , which implies that there may be a difference between the two functions. But the difference points to a conclusion inconsistent with the De Nardi et al (2021) hypothesis that savers with a surviving spouse will spend down their wealth less quickly (or exhaust and close an account later). The survivor functions in fact point to the opposite conclusion. Savers with spouses exhaust their funds and close their accounts earlier, which is consistent with two individuals consuming out of a joint account of a given size. Doing so will exhaust the account more quickly than would a single individual consuming from that same account.

The results from a Cox proportional hazard model, which provides a more formal test of the bequest motive and wealth effect, are reported in Online Appendix Table A4. A Cox hazards model estimates the conditional effects of several covariates on the probability of closing an account (the hazard rate). Children ever present and spouse ever present increase the conditional hazard of observing an account being closed, but neither is significant. The hazard increases in the saver's age and whether there is a banking panic. The hazard decreases in three measures of wealth: peak savings, a dummy variable equal to one if peak savings exceeds median peak wealth, and savings the prior year.

The full sample results point to several tentative conclusions. First, the typical turn-ofthe-century, working-class household accumulated a peak savings account balance of nearly a year's wages. Second, the typical account was open for about 13 years over which 
time the depositor added to and then drew down their accounts. Third, the rate of decumulation at older ages is slower than would be predicted, given the conditional mortality risk at older ages at the turn of the century. Fourth, a simple test for a bequest motive is inconclusive. Late and slow decumulation may be consistent with a bequest motive, but it might also result from working-class individual's continued if irregular or intermittent labor force participation at older ages. It is not unusual for men between their late fifties and early seventies to report being gainfully employed, and some elderly CSB depositors reported occupations in such physically demanding jobs as carpenter, painter, teamster, and common laborer. $^{11}$

Of the 341 CSB depositors matched to one of the censuses, only one woman reported an occupation of "lady," which is vernacular for retired. Just three men reported their occupation as "gentleman," which is also believed to imply retired. Two were in their midfifties when they reported; the third was 80 years old. In addition, the sample includes one retired clergyman. Hurd (1987) contends that modern studies that claim to refute the life cycle hypothesis when they observe continued accumulation or slow decumulation at older ages may not be drawing the right conclusions. Not all older individuals are retired and latelife contributions to bank accounts may occur after the sale of non-bank assets. It is possible, perhaps even likely, that the non-retirement of men explains the slow drawing down of account balances at older ages. Wealth-based selection into sample attrition cannot be ruled out, either. One principal insight of the life cycle hypothesis appears to hold: individuals were forward looking and based on the information available to them at the time,

\footnotetext{
${ }^{11}$ Ransom and Sutch (1986) document the phenomenon using a larger, nationally representative sample.
} 
accumulated financial wealth throughout their productive years, presumably to finance consumption in old age.

\section{Savings of male and female account holders}

Because the bank's depositors are about equally divided by sex, the saving choices of men and women may provide some insights into differences in the life-cycle concerns of men and women. Of the 160 male depositors matched to a census, 99 (61.9\%) were married with a spouse present in the household when the census was conducted. Of the 181 matched female depositors, 79 (43.6\%) were married and lived with a spouse. One of the shortcomings of census linking is that it is hard to determine whether single women married later. Women who change names upon marrying are hard to follow. For single men, especially older single men, it is hard to determine if they were always single or are widowers. Although some male and female depositors were married when they opened their accounts, few are listed as joint tenants in the CSB ledger. I treat separate accounts separately rather than as households. Spouses who opened separate accounts had personal, and unobserved reasons for doing so. Male heads of households regularly opened accounts in their own names rather than as joint accounts with their wives. These may have been treated like joint accounts and men may have anticipated that their spouses would inherit the account upon their deaths, but they may have willed terminal balances to other beneficiaries. Because the depositors' expectations and understandings with spouses and other family members are opaque, all accounts are treated as independent observations regardless of accounts contemporaneously held by resident husbands, wives, mothers, fathers, brothers, sisters, adult children, minor children, in-laws and live-in servants, all of which appear in the data. 
[Figure 6 about here]

Figure 6 plots two features of male and female depositors. The positive region of each panel plots the fixed effects point estimates of wealth-at-age along with $95 \%$ confidence intervals. The negative region provides a bar graph of the (negative of the) average number of children in the depositors' households at each age. One feature is that by age 60 male and female depositors accumulated an average of about $\$ 600$ in their accounts, though the now smaller samples generate wide confidence intervals. A second notable feature is the different trajectories for men and women in their thirties. While women added to their bank balances at a relatively steady rate, male depositors ceased adding to their accounts and appear to have drawn on their accounts in their late thirties and early forties. It was during men's thirties that home and farm ownership rates increased markedly (Atack 1989; Collins and Margo 2001), so balances may have been drawn down to finance home purchases. It was also during men's thirties and early forties that the number of children present in the household increased quickly. The slowdown in saving at these ages is consistent with the life-cycle squeeze observed by Di Matteo (1998) and Lilja and Bäcklund (2013) at about the same point in the life cycle. It remains an open question whether the pattern was anticipated and built into these depositors' life-cycle decisions, or whether they represent unanticipated interruptions of continual additions to bank balances.

The right panel of Figure 6 presents the same information for female-owned accounts. The upper region of the diagram points to a pattern of regular additions to account balances up to age 40, at which point net accumulatios slow until the depositors' mid-fifties, and then a period of net additions to accounts to age 70. A second notable difference between male and female-owned accounts is the number of children present. Female depositors had fewer 
children present than men at every age up to age 60. After age 60, however, the number of children follow separate paths: the number of children present for male depositors declines steadily to age 60, whereas the number of children present for female depositors declines to about age 60, after which the number of children increases slightly. Older female depositors, it appears, were more likely to take in grandchildren or other young children; male depositors were less likely to do so. The sample sizes here are too small for the data to generate meaningful evidence of bequest motives, but women may have continued to accumulate bank deposits into old age to provide for dependent minor children upon the depositors' deaths.

Savings of low- and high-skill workers

Savings banks were originally designed to provide safe depositories for the life-cycle savings of low-skill, low-income workers who had few alternative outlets for their modest savings (Fishlow 1961, Olmstead 1976). Skilled artisans and white-collar workers, by comparison, had alternative outlets for life-cycle savings: they invested in their businesses, the assets of which could be sold at retirement, and they were more likely to own their own homes, which could be sold or rented at retirement to finance consumption at older ages. To better understand whether less and more skilled workers accumulated savings in different ways, workers are divided into two broad skill categories based on occupations reported in the censuses. Occupations were initially grouped into four types: laborers, low-skill, highskill, and white collar. Nearly one-half of all depositors did not report an occupation, which generates relatively few observations in some skill-age-children cells, so the four skill categories are further collapsed into a low-skill category (laborers, farm laborers and low- 
skill) and high-skill category (skilled artisans and white-collar workers). ${ }^{12}$ Only 24 percent of women reported an occupation, most of whom were keepers of boardinghouses, dressmakers, teachers, or nurses. Only 12 percent of men did not report an occupation, so the sample analyzed here is nearly three-fourths male.

[Figure 7 near here]

Figure 7 provides graphs of real account balances at each age for low- and high-skill workers. ${ }^{13}$ The left panel traces a life cycle trajectory of real account balances using the fixed effects (point estimates and confidence intervals) in age. Three features are noteworthy. First, laborers and low-skill workers' net accumulations slow between their early thirties and mid-forties, which is consistent with the life-cycle squeeze hypothesis. Di Matteo (1998) and Lilja and Bäcklund (2013), who study the wealth of probated decedents, observe periods of low net additions to wealth through wealth holder's thirties. ${ }^{14}$ They note, however, that the earlier squeeze was due to greater debt rather than fewer assets, which may have followed from artisans borrowing to start a business rather than from reducing savings to provide for children. Second, low-skill workers appear to contribute to their savings accounts up to their late fifties to early sixties, which is consistent with the surveys of working-class individuals’ beliefs about their expected working lives and life expectancies.

\footnotetext{
12 Besides laborers, the low-skill category includes such jobs as brickmakers, carpet-factory operatives, carters, coachmen, and drivers, gardeners, and teamsters. High-skill occupations include such jobs as cabinetmakers, carpenters, printers, railroad inspectors, and telegraphers. White-collar jobs include attorneys, clergy, clerks, merchants, salesmen, and physicians.

${ }^{13}$ A comparable graph of wealth-at-age for depositors not reporting an occupation resembles the female depositor graph in Figure 6 and discussed above.

${ }^{14}$ Unlike the results reported here, Lilja and Backlund (2013) find that the slowdown in savings was more pronounced among skilled artisans. They argue that the pattern is consistent with the age at which skilled artisans buy into or establish their own business. They are not convinced that the slowdown is due to providing for more young children.
} 
Third, low-skill workers do not draw down their accounts after age 70, but this may be a consequence of wealth-based selection into mortality discussed earlier.

The most notable feature of the right panel of skilled and white-collar workers is the gradual and, relative to low-skill workers, modest accumulation of savings bank balances, though it should be kept in mind that the confidence intervals overlap at most ages. Peak average savings for low-skill workers exceed $\$ 1,500$ and occurs around age 60. For highskill workers average peak wealth is about one-third that of low-skill workers at age 60 .

Anbinder, ÓGráda, and Wegge (2019) uncover a comparable pattern of greater savings among low-skill than high-skill workers among famine-era Irish immigrants who opened accounts at the Emigrant Industrial Savings Bank in New York City. They posit that lowskill workers' income variance was higher in both the short-term and over the life cycle, so that low-skill workers built up larger precautionary bank balances to escape the hand-tomouth existence that, absent sufficient precautionary savings, followed from recurrent seasonal and cyclical unemployment spells or extended periods of breadwinners' illnesses. Some may have built up net eggs as a substitute for life insurance for those left behind at the account holder's death. The average Irish saver in mid-nineteenth-century New York City built up a savings account equal to about six months' wages. By comparison, the average low-skill worker in Cornwall had by age 60 built up an account equal to about 20 months' wages.

While part of the bank wealth difference observed between workers of different skill levels is attributable to income risk, the observed differences in the financial wealth of lowand high-skill workers are likely attributable, at least in part, to differences in household wealth that is not observed in the bank data. Artisans and merchants are likely to have equity 
in their enterprises. Master mechanics owned their tools; blacksmiths owned fire and forge. Retailers owned buildings and fixtures. Skilled and white-collar workers were more likely to own their homes; laborers rented. House values reported in New York's 1875 census exhibit expected differences in housing wealth by skill. Among those few reporting a value, the average house value of laborers and low-skill workers is $\$ 1,259$. The average house value of high-skill workers is $\$ 3,357$ and that of white-collar workers is $\$ 5,758$. Although only a small fraction of the savers is matched to the 1875 census so any conclusion must remain tentative, the evidence points to working-class people who owned relatively little in the way of durable goods and real estate relied more on savings account balances to finance consumption through old age. Skilled and white-collar workers built up house and business equity and accumulated more consumer durables, which, though lumpy, could be sold or leased to finance consumption in old age or passed on as bequests on their deaths. At their inception, savings banks were designed to serve as safe repositories for precautionary and life-cycle savings of working-class households, though there is some question whether the banks moved away from this focus over time (Fishlow 1961, Olmstead 1976). The CSB, at least, appears to have served as a repository for life-cycle savings among the town's working-class savers.

\section{The savings of native- and foreign-born depositors}

Anbinder (2012), Anbinder, ÓGráda, and Wegge (2019) provide studies of saving patterns of famine-era Irish immigrants at the Emigrant Industrial Savings Bank of New York City. They do not provide detailed statistical analysis of EISB savers' accounts, but they argue that the patterns of deposits and withdrawals are consistent with precautionary 
motives. They do not address whether immigrant savers followed life-cycle strategies. The CSB data offer some preliminary insights into any differences between native- and foreignborn savers. Any conclusions regarding differences between these groups are preliminary, however, because the sample of foreign-born savers is too small to generate savings estimates before age 30 and the sample size shrinks quickly after age 60 .

[Figure 8 near here]

Figure 8 plots the point estimates and confidence intervals derived from fixed-effects regressions of wealth on age for 268 native- and 68 foreign-born depositors, 58 of whom are from Ireland and Great Britain. The left panel shows that native-born savers followed a life cycle trajectory like that observed for the full sample, namely a long-term pattern of continuous additions to account balances, with a slowdown in the savers' forties. The life cycle pattern exhibited by foreign-born savers is distinctive. The foreign born have zero predicted savings up to age 40; although some estimates are negative, they are not statistically different from zero, which is of course the minimum savings account balance. After age forty, however, foreign-born savers exhibit a 20-year period of rapid accumulation that peaks at an average value near $\$ 1,000$ at age 60 .

Slow accumulation through their thirties followed by rapid saving among the foreign born relative to natives is consistent with differences in demographic characteristics between the two groups, the costs of migration, and the likelihood that younger immigrants remitted some fraction of their savings to Old World relatives. People tend to immigrate in their late teens and twenties, and it may have taken a few years for immigrants to find their way to Cornwall after arriving in America. Moreover, Cohn (2005) estimates the cost of steamship passage in steerage in 1875 between $£ 5$ and $£ 5.5$ or about $\$ 30$ per person at then-current 
exchange rates. If migrants traveled with spouses or families, a large proportion of premigration savings would have been spent on the cost of migration itself, which would delay the age at account opening, as well as the initial deposit. Foreign-born savers (42 years) on average opened their accounts four years later than natives (38 years). The foreign born had more children in the household, 1.8 compared to 1.1 for natives. The opening deposit for the foreign born (\$128) was 84\% as much as for the native born (\$152). Migration delayed the age at which accounts were opened, in Cornwall at least; it is not known whether migrants had accounts in some other bank before their move to Cornwall. And, because migrants tended to work at less-skilled occupation than the native born, their savings accounts likely accounted for a larger share of their overall wealth.

Anbinder (2012) argues that the accumulated savings of famine-era Irish immigrants at New York City’s Emigrant Industrial Savings Bank reveal a remarkable resilience and an unexpected ability to achieve financial stability. The experience of the Cornwall's immigrant savers points to a similar though qualified conclusion. While peak financial savings of the foreign born exceed that of native-born savers, the average house value of the foreign born $(\$ 1,165)$ reported in the 1875 New York census is less than one-half the value reported by the native born $(\$ 3,282)$. Immigrants saved and acquired assets, but it appears that they did not diversify to the same extent as the native born.

\section{Concluding remarks}

Nineteenth-century social reformers encouraged working-class households to take greater responsibility for their own financial well-being, and several new financial intermediaries, including building and loan associations, beneficial societies, and industrial 
life insurance companies, offered an array of personal finance options tailored to meet the needs of working-class households. One of the more popular options in the northeastern United States was the savings bank. Small-town savings banks were nonprofit organizations designed to encourage working-class households to save by offering safe repositories that paid above-market returns on modest balances. Savings banks' advocates believed that households that systematically contributed to a savings account were more likely to remain self-reliant during spells of seasonal and cyclical unemployment. Savings banks also encouraged self-sufficiency in old age.

This study provides evidence on how small-town households used one turn-of-thecentury savings bank. The evidence suggests that Cornwall, New York’s citizens who kept accounts open for five years or more at the town's lone savings bank accumulated wealth in a fashion consistent with the life cycle hypothesis even though account balances do not display the hump shape characteristic of life cycle choices in retirement. Men and women, low-skill and white-collar workers, the native-born and immigrants alike added to savings bank balances between their twenties and sixties. Contributions sometimes slowed or were interrupted at ages at which growing households made continued contributions to precautionary and retirement balances difficult.

Savings account balances do not follow the rapid old-age or post-retirement decumulation predicted by the life cycle hypothesis, however. One explanation might be that turn-of-the-century men (and other members of their families) neither anticipated nor experienced an extended period of retirement in the modern sense of the term. They anticipated and experienced an extended period of declining and irregular labor force participation after their mid-fifties. Men continued to work into their sixties and even their 
seventies, though irregularly and at different and less strenuous occupations than they had followed in their youths (Lee 2001, Sutch 2010). Workers who never completely exited the labor force could maintain their consumption in old age without rapidly drawing down their accounts.

A second potential reason that retirement-age men and women did not draw on their savings accounts was a strong bequest motive. Much more work needs to be done to understand the full array of household assets in old age before we can confirm whether savers held strong bequest preferences. The results of tests inspired by Hurd (1987) and De Nardi et al (2021) are inconsistent with a strong bequest motive, however. Older savers who were more likely to have surviving children did not close their accounts later than those less likely to have surviving children. Older savers who were more likely to have a surviving spouse were also no less likely to close an account than savers less likely to have a surviving spouse. But it should be kept in mind that selective attrition from the sample at older ages may account for my failure to find the predicted hump shape of savings at age. If wealth and health were positively correlated and general health was negatively correlated with conditional mortality risk at older ages, less wealthy savers exited the sample earlier and at higher rates, which will upwardly bias estimated wealth.

The conclusion that is warranted, pending additional research, is that by age sixty smalltown, working-class savings bank depositors accumulated account balances equal in value to about one year's wages, maybe more. If consumption during early retirement declined at the turn of the century, as it is believed to do now, one year's wages augmented by income earned from part-time employment might sustain a household for the two to three years of 
retirement anticipated by cohorts entering old age at the turn of the century (Aguila, Attanasio and Meghir 2011). 
Aguila, E., Attanasio, O., \& Meghir, C. (2011). Changes in consumption at retirement: evidence from panel data. Review of Economics and Statistics 93(3), 1094-1099.

Alter, G., Goldin, C., \& Rotella, E. (1994). The savings of ordinary American: the Philadelphia Saving Fund Society in the mid-nineteenth century. Journal of Economic History 54(4), 735767.

Anbinder, T. (2012). Moving beyond 'rags to riches': New York’s Irish famine immigrants and their surprising savings accounts. Journal of American History 99(3), 741-770.

Anbinder, T., ÓGráda, C., \& Wegge, S. A. (2019). Networks and opportunities: a digital history of Ireland’s great famine refugees in New York. American Historical Review 124(5), 15911629.

Anbinder, T., Connor, D., ÓGráda, C., \& Wegge, S. A. (2021). The problem of false positives in automated census linking: evidence from nineteenth-century New York’s Irish immigrants. UCD Centre for Economic Research Working Paper WP2021/14.

Angrist, J. D., \& Pischke, J-S. (2009). Mostly Harmless Econometrics: An Empiricist’s Companion. Princeton University Press.

Atack, J. (1989). The agricultural ladder revisisted: a new look at an old question with some data for 1860. Agricultural History 63(1), 1-25.

Atack, J., \& Bateman, F. (1981). The “egalitarian ideal” and the distribution of wealth in the northern agricultural community: a backward look. Review of Economics and Statistics 63(1), 124129.

Averett, S., Bodenhorn, H., \& Staisiunas, J. (2005). Unemployment risk and compensating differentials in late-nineteenth-century New Jersey. Economic Inquiry 43(4), 734-749. 
Bailey, M. J., Cole, C., Henderson, M., \& Massey, C. (2020). How well do automated linking methods perform? Lessons from US historical data. Journal of Economic Literature 58(4), 997-1044.

Bleakley, H., Cain, L., \& Ferrie, J. (2015). Amidst poverty and prejudice: black and Irish Civil war veterans. In A. Greif, L. Keisling, J. V. C. Nye (Eds.), Institutions, Innovation, and Industrialization: Essays in Economic History and Development. Princeton University Press.

Bleakley, H., \& Ferrie, J. (2016). Shocking behavior: random wealth in antebellum Georgia and human capital across generations Quarterly Journal of Economics 131(3), 1455-1495.

Bodenhorn, H. (2015). The Color Factor: The Economics of African-American Well-Being in the Nineteenth-Century South. Oxford University Press.

Bodenhorn, H. (2019). Were nineteenth-century industrial workers permanent income savers? Southern Economic Journal 85(4), 1286-1310.

Boulding, K. E. (1966). Economic Analysis, Volume I: Microeconomics (4 ${ }^{\text {th }}$ ed.). Harper \& Row. Bourdieu, J., Kesztenbaum, L., \& Postel-Vinay, G. (2011). Thrifty pensioners: pensions and saving in France at the turn of the twentieth century. Journal of Economic History 71(2), 383-412.

Browning, M., \& Crossley, T. F. (2001). The life-cycle model of consumption and saving. Journal of Economic Perspectives 15(3), 3-22.

Burnette, J. (2021). Missing work: absenteeism at Pepperell Manufacturing Co. Cliometrica 15(x), 755-786.

Cagetti, M. (2003). Wealth accumulation over the life cycle and precautionary savings. Journal of Business \& Economic Statistics 21(3), 339-353. 
Carroll, C. D. (1997). Buffer-stock saving and the life cycle / permanent income hypothesis. Quarterly Journal of Economics 112(1), 1-55.

Carter, S. B., Gartner, S. S., Haines, M. R., Olmstead, A. L., Sutch, R., \& Wright, G. (Eds.). (2006). Historical Statistics of the United States: Millennial Edition. Cambridge University Press.

Cohn, R. L. (2005). The transition from sail to steam in immigration to the United States. Journal of Economic History 65(2), 469-495.

Collins, W. J., \& Margo, R. A. (2001). Race and home ownership: a century-long view. Explorations in Economic History $\mathrm{x}(\mathrm{x})$, pp.

Collins, W. J., \& Zimran. A. (2019). The economic assimilation of Irish famine immigrants to the United States. Explorations in Economic History 74. doi.org/10.1016/j.eeh.2019.101302Conley, T. G., \& Galenson, D. W. (1994). Quantile regression analysis of censored wealth data. Historical Methods 27(4), 149-165.

Davidoff, T., Brown, J. R., \& Diamond, P. A. (2005). Annuities and individual welfare. American Economic Review 95(5), 1573-1590.

Davis, J. (2004). An annual index of U.S. industrial production, 1790-1915. Quarterly Journal of Economics 119(4), 1177-1215.

Davis, L., \& Gallman, R. E. (1978). Capital formation in the United States during the nineteenth century. In P. Mathias \& M. M. Postan (Eds.), The Cambridge Economic History of Europe, vol. 7, part 2 (pp. 1-69). Cambridge University Press.

De Nardi, M., French, E., Jones, J. B., \& McGee, R. (2021). Why do couples and single save during retirement? National Bureau of Economic Research working paper \#28828.

Deaton, A. (1991). Saving and liquidity constraints. Econometrica 59, 1221-1248. 
Deneweth, H., Glederblom, O., \& Jonker, J. (2014). Microfinance and the decline of poverty: evidence from the nineteenth-century Netherlands. Journal of Economic Development 39(1), 79-110.

Di Matteo, L. (1997). The determinants of wealth and asset holding in nineteenth-century Canada: evidence from microdata. Journal of Economic History 57(4), 907-934.

Di Matteo, L. (1998). Wealth accumulation and the life-cycle in economic history: implications of alternative approaches to data. Explorations in Economic History 35, 296-324.

Ferrie, J. P. (1994). The wealth accumulation of antebellum European immigrants to the U.S., 184060. Journal of Economic History 54(1), 1-33.

Fishback, P. V. (1998). Operations of 'unfettered' labor markets: exit and voice in American labor markets at the turn of the century. Journal of Economic Literature 36(3), 722-765.

Fishlow, A. (1961). The trustee savings banks, 1817-1861. Journal of Economic History 21(1), 2640.

Gordon, R. J. (2016). The Rise and Fall of American Growth: The U.S. Standard of Living since the Civil War. Princeton University Press.

Gregson, M. E. (1996). "Wealth accumulation and distribution in the Midwest in the late nineteenth century.” Explorations in Economic History 33(4), 524-538.

Guinnane, T. W., \& Streb, J. (2011). Moral hazard in a mutual health insurance system: German Knappschaften, 1867-1914. Journal of Economic History 71(1), 70-104.

Haines, M. R. (1979). Industrial work and the family life cycle, 1889-1890. Research in Economic History 4, 289-356. 
Heckman, J., \& Robb, R. (2012). Using longitudinal data to estimate age, period and cohort effects in earnings equation. In W. M. Mason \& S. E. Feinberg (Eds.), Beyond the Identification Problem (pp. 137-150). Springer Verlag.

Jalil, A. 2015. A new history of banking panics in the United States, 1825-1929: construction and implications. American Economic Journal: Macroeconomics 7(3), 295-330.

Kantor, S. E., \& Fishback, P. V. (1996). Precautionary saving, insurance, and the origins of workers' compensation. Journal of Political Economy 104(2), 419-442.

Kearl, J. R., \& Pope, C. L. (1983). The life cycle in economic history. Journal of Economic History 43(1), 149-158.

Kearl, J. R., Pope, C. L., \& Wimmer, L. T. (1980). Household wealth in a settlement economy: Utah, 1850-1870. Journal of Economic History 40(3), 477-496.

Kelly, M., \& ÓGráda, C. (2000). Market contagion: evidence from the panics of 1854 and 1857. American Economic Review 90(5), 1110-1124.

King, M. (1985). The economics of saving: a survey of recent contributions. In K. J. Arrow \& S. Konkapohja (Eds.), Frontiers in Economics (pp.227-294). Basil Blackwell.

Kotlikoff, L. J., \& Spivak, A. (1981). The family as an incomplete annuities market. Journal of Political Economy 89(2), 372-391.

Lawrence, D. S. (1878). D. S. Lawrence \& Co’s Orange County Directory for 1878-79. Newburgh, New York.

Lee, C. (2001). The expected length of male retirement in the United States, 1850-1990. Journal of Population Economics 14(4), 641-650.

Lee, C. (2003). Labor market status of older males in the United States, 1880-1940. NBER wp. 9550. 
Lee, C. (2005). Wealth accumulation and the health of union army veterans, 1860-1870. Journal of Economic History 65(2), 352-385.

Lilja, K., \& Bäcklund, D. (2013). To navigate the family economy over a lifetime: life-cycle squeezes in pre-industrial Swedish small towns. European Review of Economic History 17(2), 171-189.

Lockwood, L. M. (2012). Bequest motives and the annuity puzzle. Review of Economic Dynamics 15(2), 226-243.

Marshall, A., \& Marshall, M. P. (1879). The Economics of Industry. Macmillan \& Co.

Margo, R. A. (1993). The labor force participation of older Americans in 1900: further results. Explorations in Economic History 30(x), 409-423.

Mason, W. M., \& Wolfinger, N. H. (2001). Cohort analysis. UCLA Online Working Paper Series. https://escholarship.org/uc/item/8wc8v8cv.

Modigliani, F. (1986). Life cycle, individual thrift, and the wealth of nations. Science 234(4777), 704-712.

Modigliani, F., \& Brumberg, R. (1954). Utility analysis and the consumption function: an interpretation of cross-section data. In Kurihara, K. (Ed.), Post-Keynesian Economics, (pp. 388-436). Rutgers University Press.

Murray, J. E. (2007). Origins of American Health Insurance: A History of Industrial Sickness Funds. Yale University Press.

New Jersey Bureau of Statistics of Labor and Industries. (1889). Twelfth Annual Report. John L. Murphy Publishing Co.

New York (State). (1819). Laws of the State of New York, Passed at the Forty-Second Session of the Legislature. J. Buel, Printer to the State. 
New York (State). Superintendent of Banks. (1873 - 1911). Annual Report of the Superintendent of Banks Relative to Savings Banks, Trust Companies, Safe Deposit Companies and Miscellaneous Corporations. State Printer.

New York (State). Superintendent of Banks. (1893). Report of the superintendent of banks relative to building and loan associations and co-operative savings and loan associations. Documents of the Assembly of the State of New York, Vol. XVI, Document No. 85. James. B. Lyon, State Printer.

New York (State). Superintendent of Banks. (1911). Annual report of the superintendent of banks relative to savings and loan associations, for the year 1910. Documents of the Senate of the State of New York, Document No. 19. J. B. Lyon Company, State Printers.

North, D. (1979). Capital accumulation in life insurance between the Civil War and the investigation of 1905. In W. Miller (ed.), Men in Business: Essays on the Historical Role of the Entrepreneur. Greenwood Press.

ÓGráda, C. (2009). Savings banks, famine and financial contagion: Ireland in the 1840s and 1850s. Irish Economic and Social History 36, 21-36.

ÓGráda, C., \& White, E. N. (2003). The panics of 1854 and 1857: a view from the Emigrant Industrial Savings Bank. Journal of Economic History 63(1), 213-240.

Olmstead, A. L. (1976). New York City Mutual Savings Banks, 1819-1861. University of North Carolina Press.

Ott, J. C. (2011). When Wall Street Met Main Street: The Quest for an Investors' Democracy. Harvard University Press.

Paxson, C. H. 1992. Using weather variability to estimate the response of savings to transitory income in Thailand. American Economic Review 82(1), 15-33. 
Perriton, L., \& Henderson, S. (2020). For all intents and purposes: depositor behaviour and strategy in a London savings bank. Enterprise \& Society, 1-36. https://doi.org/10.1017/eso.2020.48

Price, D. A., \& Walter, J. R. (2016). Private efforts for affordable mortgage lending before Fannie and Freddie. Federal Reserve Bank of Richmond Economic Quarterly 102(4), 321-351.

Ransom, R. L., \& Sutch, R. 1986. The labor of older Americans: retirement of men on and off the job, 1870-1937. Journal of Economic History 46(1), 1-30.

Rockman, S. (2009). Scraping By: Wage Labor, Slavery, and Survival in early Baltimore. Johns Hopkins University Press.

Romer, C. D. (1989). The prewar business cycle reconsidered: new estimates of gross domestic product, 1869-1908. Journal of Political Economy 97(1), 1-37.

Ross, D. (2013). Savings bank depositors in a crisis: Glasgow 1847 and 1857. Financial History Review 20(2), 183-208.

Ruggles, S., Flood, S., Foster, S., Goeken, R., Pacas, J., Schouweiler, M., \& Sobek, M. 2021. IPUMS USA: Version 11.0 [dataset]. Minneapolis. https://doi.org/10.18128/D010.V11.0.

Scott, P. M., \& Walker, J. (2012). Working-class household consumption smoothing in interwar Britain. Journal of Economic History 72(3), 797-825.

Shefrin, H. M., \& Thaler, R. H. (1988). The behavioral life-cycle hypothesis. Economic Inquiry 26(4), 609-643.

Smith, A. 1909. An Inquiry into the Nature and Causes of the Wealth of Nations. Bullock, C. J. (ed.). P. F. Collier \& Son Company.

Soltow, L. (1975). Men and Wealth in the United States, 1850-1870. Yale University Press.

Steckel, R. H. (1994). Census manuscript schedules matched with property tax lists: a source of information on long-term trends in wealth inequality. Historical Methods 27(2), 71-85. 
Sutch, R. (2010). Hard work, nonemployment, and life-cycle saving in the United States during the nineteenth century. Working paper, University of California, Riverside.

United States Census Office. (1860). Eighth Census. Instructions to U. S. Marshals. Instructions to Assistants. Geo. W. Bowman, Public Printer.

Wadhwani, R. D. (2002). Banking from the bottom up: the case of migrant savers at the Philadelphia Saving Fund Society during the late nineteenth century. Financial History Review 99(1), 4163.

Wegge, S., Anbinder, T., \& ÓGráda, C. (2017). Immigrants and savers: a rich new database on the Irish in 1850s New York. Historical Methods 50(3), 144-155.

Wolff, E. N. (1981). The accumulation of household wealth over the life cycle: a microdata analysis. Review of Income and Wealth 27(1), 75-96. 


\title{
FIGURES AND GRAPHS
}

\author{
Figure 1: Rank distribution of New York Savings Banks, 1889
}

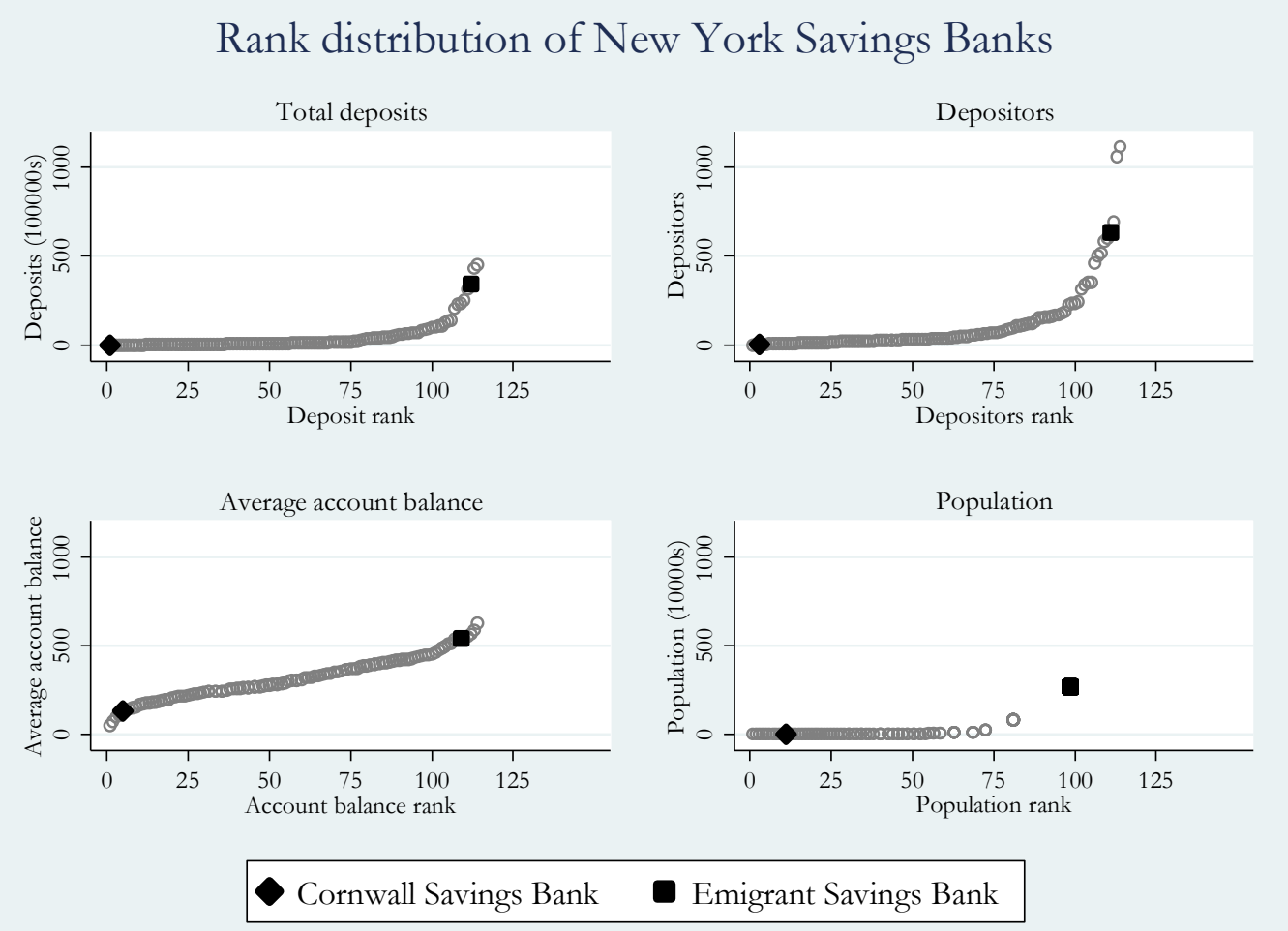

Note: Figure 1 plots the rank order of New York savings banks from smallest to largest on the horizontal axis against four measures of bank size (clockwise from upper left): total deposits, number of depositors, population of town in which bank operates, and average account balance. Each gray circle signifies a savings bank. The Cornwall Savings Bank place in the distribution is designated with the black diamond. For comparative purposes, the place of the Emigrant Industrial Savings Bank is designated with a black square.

Sources: New York Superintendent of Banks (1889). 
Figure 2: Age at account opening and account closing at Cornwall Savings Bank, 1871-1911

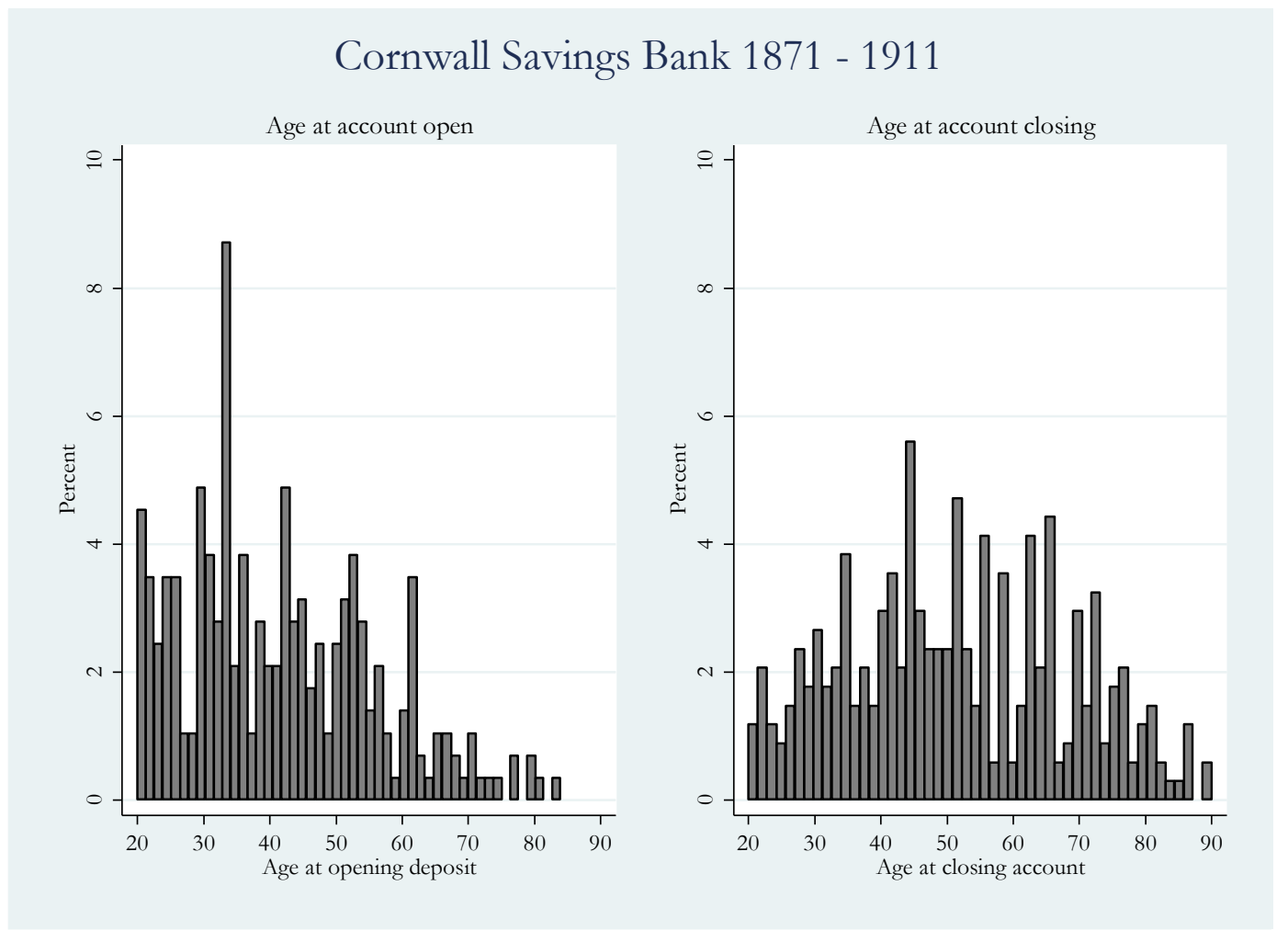

Note: The graphs show the distribution of ages at which all account holders opened their accounts (left panel) and closed their accounts (right panel). The graphs reveal that accounts were opened and closed over the entire life cycles of nineteenth-century New Yorkers. The left panel points to account openings declining with age after the mid-30s. The right panel points to account closings occurring at a steady rate between the mid-40s and mid-60s, after which the rate declines.

Sources: author's calculations from CSB records and decennial censuses. 
Figure 4: Full-sample age fixed effects and quadratic estimates of wealth-at-age

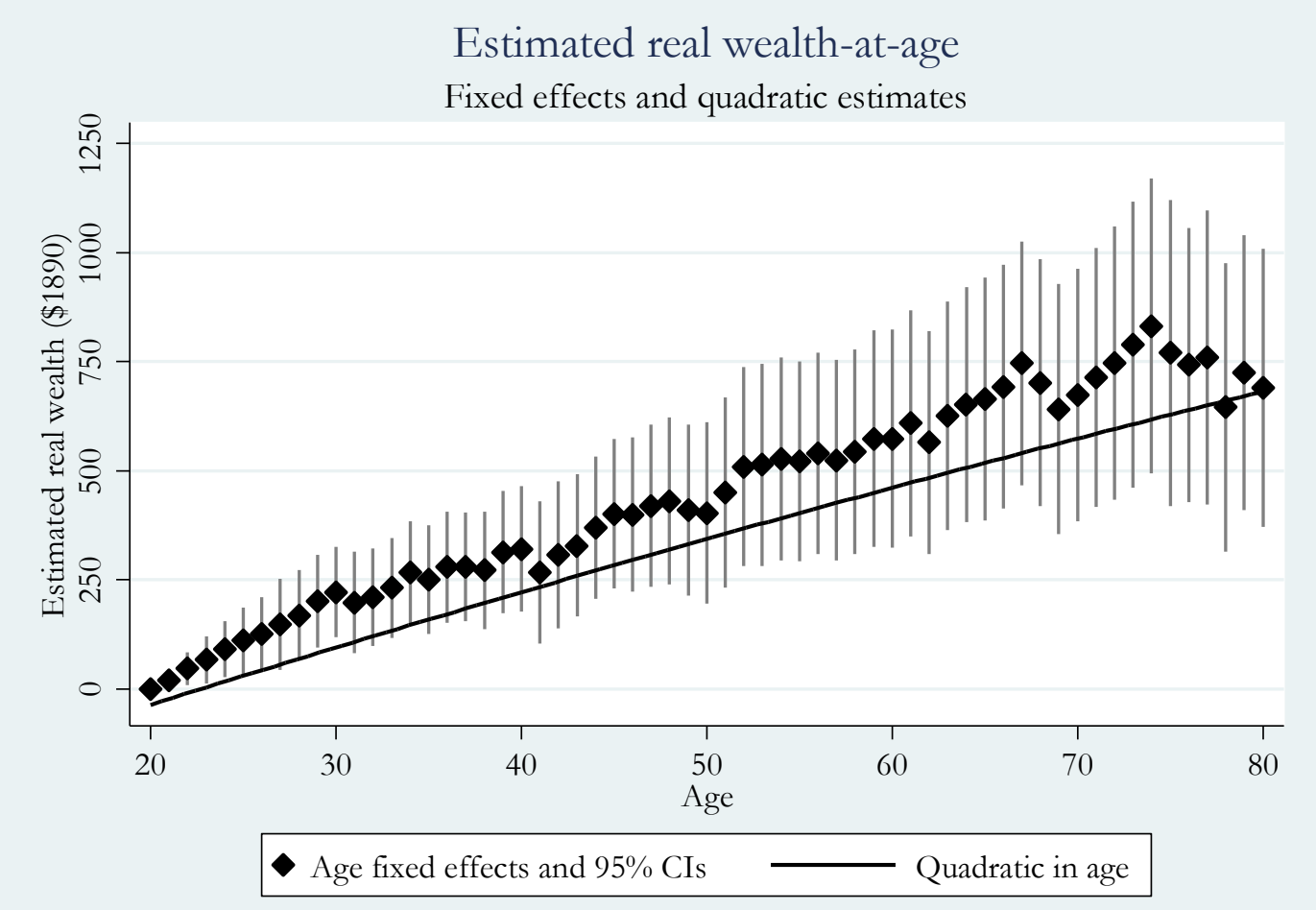

Notes: The figure reports the estimated age coefficients (diamonds) from Equation 1 and the 95\% confidence intervals of the age coefficients (gray vertical spikes) and the smoothed estimates of wealth-at-age derived from Equation 2 (black curve), which regresses wealth on age and age-squared. Both equations also include controls for era, recession years, and number of children in the household. Sources: author's calculations from CSB records and decennial censuses. 
Figure 5

Kaplan-Meier Survival Plots for Savers with Children and Spouses

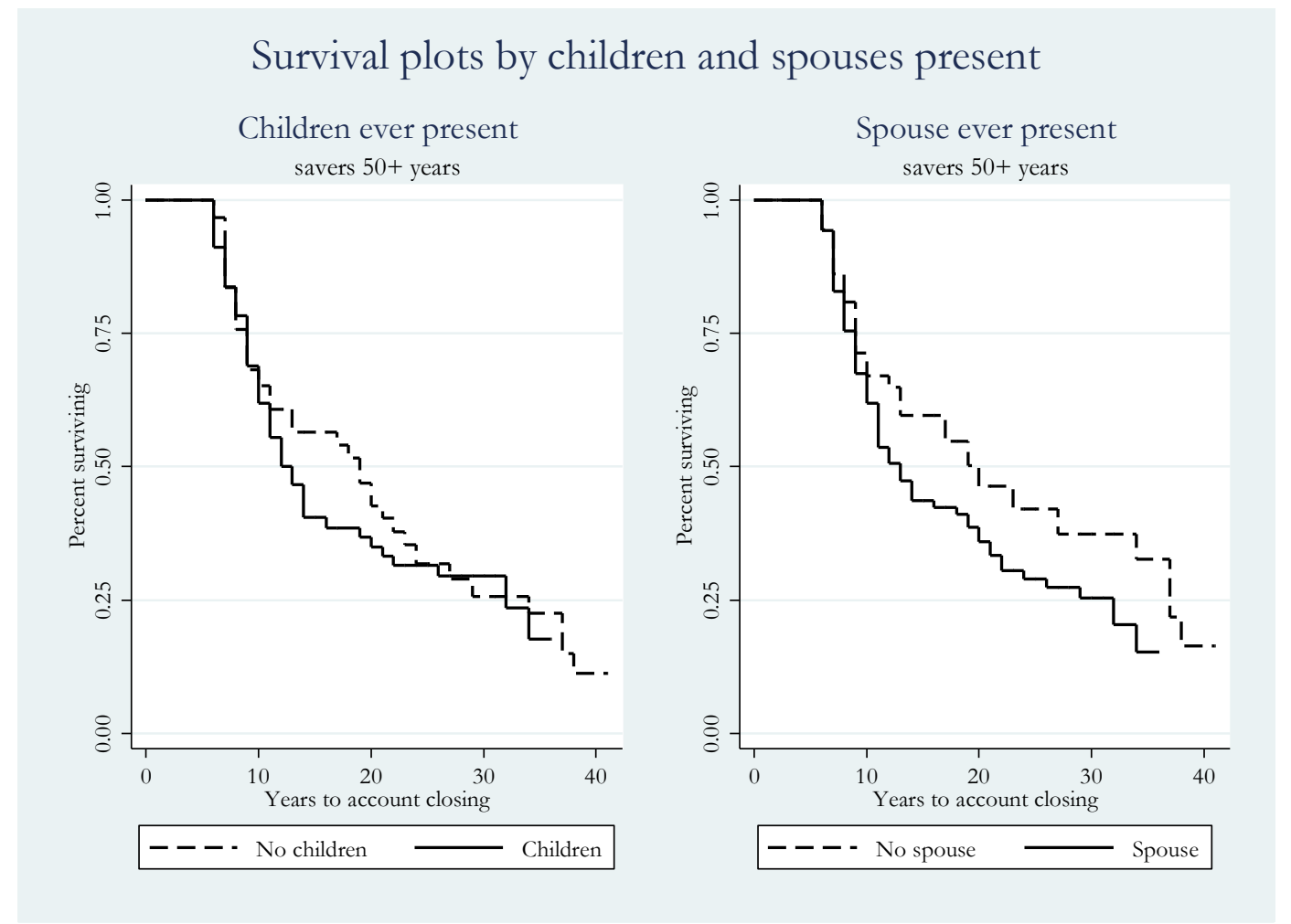

Notes: the graphs provide 
Figure 6: Estimated savings at age and children in household for male and female savers

\section{Estimated savings at age and children in household}
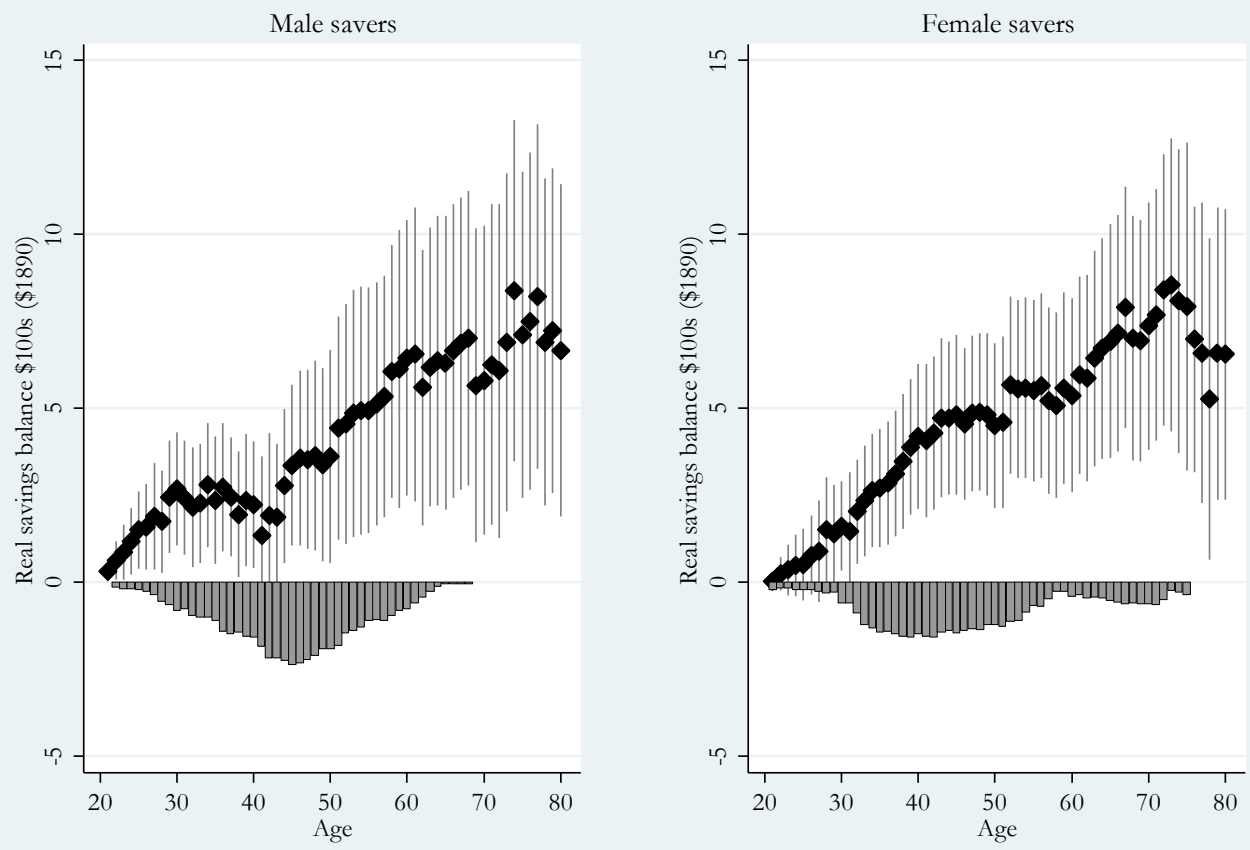

Note: The upper panel (positive range) of Figure 6 plots point estimates of wealth-at-age from fixed effects regression of wealth on age, eras, and children in the household. Wealth is measured in $\$ 100$ s. The 95\% standard error bars are clustered on the depositor. The lower panel (negative range) of Figure $x$ plots the (negative of the) average number of children in households by age of household head. The graph illuminates the extent of the life-cycle squeeze, which is believed to occur early in households' child-bearing years and at later ages as productivity and wages decline. Sources: author's calculations from CSB data and decennial censuses. 
Figure 7: Estimated wealth at age for low- and high-skill workers

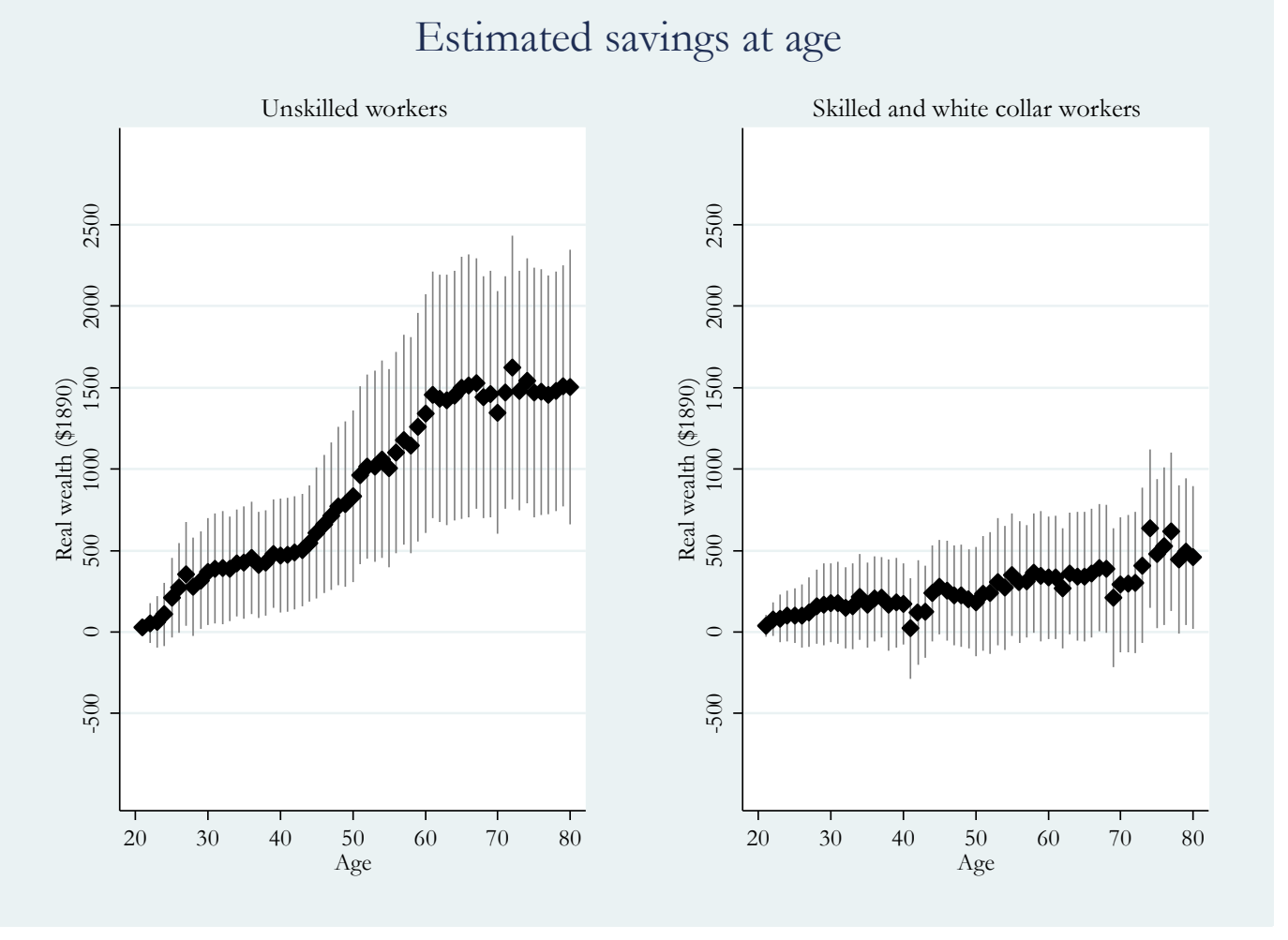

Notes: The figure reports the estimates age coefficients (diamonds) from Equation 1 and the 95\% confidence intervals of the age coefficients (vertical gray spikes) and the smoothed estimates of the wealth-at-age estimated from Equation 2 (black curve), which regresses the real value of wealth on age and age-squared. Both equations also include controls for eras and number of children in the household.

Sources: author's calculation from CSB records and decennial censuses. 
Figure 8: Estimated savings at age for native- and foreign-born depositors

\section{Estimated savings at age}
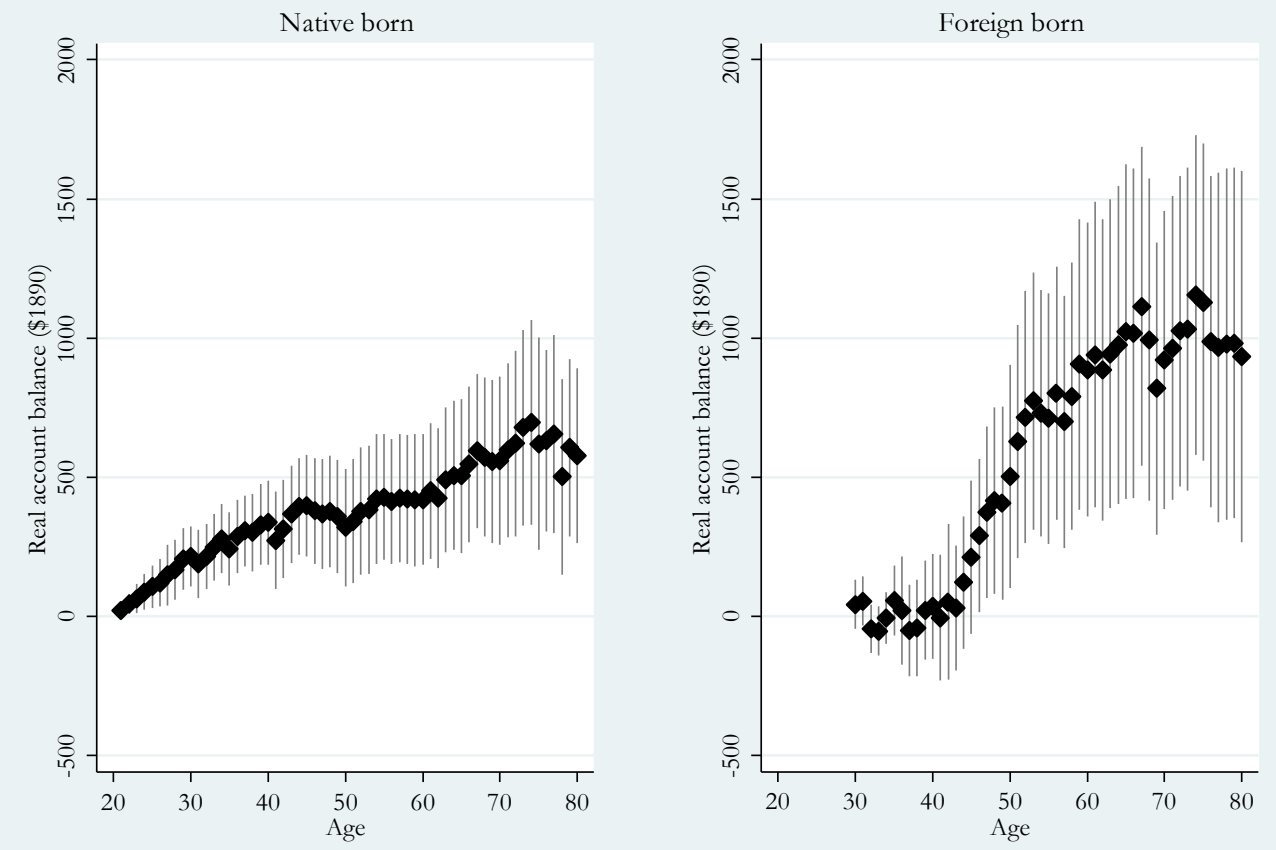

Notes: The figure reports the estimates age coefficients (diamonds) from Equation 1 and the 95\% confidence intervals of the age coefficients (vertical gray spikes) for native- and foreign-born depositors. The estimated equations also include controls for eras, recession years and number of children in the household.

Sources: author's calculations from CSB and decennial censuses. 


\section{TABLES}

\begin{tabular}{|c|c|c|c|c|c|c|c|c|}
\hline \multicolumn{9}{|c|}{ Table 1} \\
\hline \multicolumn{9}{|c|}{ Historical studies of life cycle savings } \\
\hline & \multicolumn{3}{|c|}{ A: Decennial federal censuses } & & & & & \\
\hline Author(s) & Date & Type & Wealth & Years & Geography & Obs & Age at peak & Technique \\
\hline Soltow & 1975 & $\mathrm{X}$ & $\mathrm{R} / \mathrm{P}$ & $1850-1870$ & US & 9900 & mid-40s & OLS \\
\hline Kearl, Pope and Wimmer & 1980 & $\mathrm{P}$ & $\mathrm{R}$ & $1850-1870$ & Utah & 19137 & 52.3 & OLS \\
\hline Atack and Bateman & 1981 & $\mathrm{X}$ & $\mathrm{R} / \mathrm{P}$ & 1860 & Old Northwest & \multirow{2}{*}{21118} & 63.3 & OLS \\
\hline Atack and Bateman & 1981 & $\mathrm{X}$ & $\mathrm{R} / \mathrm{P}$ & 1860 & Northeast & & 60.9 & OLS \\
\hline Kearl and Pope & 1983 & $\mathrm{X}$ & $\mathrm{R} / \mathrm{P}$ & 1870 & Utah & 4782 & 50.0 & OLS \\
\hline Galenson and Pope & 1989 & $\mathrm{X}$ & $\mathrm{R} / \mathrm{P}$ & 1860 & Iowa & 460 & 49.9 & OLS \\
\hline Steckel & 1990 & $\mathrm{P}$ & $\mathrm{R} / \mathrm{P}$ & $1850-1870$ & US & 1581 & na & Gini \\
\hline Galenson & 1991 & $\mathrm{X}$ & $\mathrm{R} / \mathrm{P}$ & 1860 & Chicago & 1317 & 49.7 & OLS \\
\hline Ferrie & 1994 & $\mathrm{X}$ & $\mathrm{R}$ & 1850 & US & 1473 & 51.5 & OLS \\
\hline Ferrie & 1994 & $\mathrm{X}$ & $\mathrm{R}$ & 1860 & US & 1191 & 61.3 & OLS \\
\hline Ferrie & 1994 & $\mathrm{P}$ & $\mathrm{R}$ & $1850-1860$ & US & 509 & 397.5 & $\mathrm{FE}$ \\
\hline Ferrie & 1994 & $\mathrm{P}$ & $\mathrm{R}$ & $1850-1860$ & US & 509 & 63.9 & $\mathrm{RE}$ \\
\hline Conley and Galenson & 1994 & $\mathrm{X}$ & $\mathrm{R}$ & 1860 & Chicago & 6604 & 52.4 & OLS \\
\hline Conley and Galenson & 1994 & $\mathrm{X}$ & $\mathrm{R}$ & 1860 & Chicago & 2518 & 50.5 & Tobit \\
\hline Conley and Galenson & 1994 & $\mathrm{X}$ & $\mathrm{R}$ & 1860 & Chicago & 6604 & 50.9 & Quantile \\
\hline Conley and Galenson & 1994 & $\mathrm{X}$ & $\mathrm{P}$ & 1860 & Chicago & 6604 & 48.6 & Quantile \\
\hline Gregson & 1996 & $\mathrm{X}$ & $\mathrm{R} / \mathrm{P}$ & 1870 & Missouri & 1693 & 69.2 & OLS \\
\hline Gregson & 1996 & $\mathrm{X}$ & $\mathrm{R} / \mathrm{P}$ & 1870 & Missouri & 1026 & 73.1 & TSLS \\
\hline Herscovici & 1998 & $\mathrm{P}$ & $\mathrm{R}$ & $1850-1860$ & Newburyport, MA & 649 & 48.7 & Quantile \\
\hline Herscovici & 1998 & $\mathrm{P}$ & $\mathrm{R}$ & $1850-1860$ & Newburyport, MA & 1512 & 45.1 & Quantile \\
\hline Lee & 2005 & $\mathrm{P}$ & $\mathrm{R} / \mathrm{P}$ & $1860-1870$ & Jnion Army veteran & 978 & na & OLS \\
\hline Bodenhorn and Ruebeck & 2007 & $\mathrm{X}$ & $\mathrm{R} / \mathrm{P}$ & 1860 & Black men & 11592 & 62 & OLS \\
\hline Bodenhorn and Ruebeck & 2007 & $\mathrm{X}$ & $\mathrm{R} / \mathrm{P}$ & 1860 & Black women & 4269 & 38.5 & OLS \\
\hline \multirow[t]{2}{*}{ Sutch } & 2010 & $\mathrm{X}$ & $\mathrm{R} / \mathrm{P}$ & 1870 & US & 47569 & mid-60s & OLS \\
\hline & \multicolumn{3}{|c|}{ B: Property tax and probate } & & & & & \\
\hline Steckel & 1994 & $\mathrm{X}$ & $\mathrm{R}$ & 1850 & Massachusetts & 1174 & 54.4 & OLS \\
\hline Steckel & 1994 & $\mathrm{X}$ & $\mathrm{R}$ & 1850 & Ohio & 1171 & 48.1 & OLS \\
\hline Di Matteo & 1997 & $\mathrm{X}$ & $\mathrm{T}$ & 1892 & Ontario & 3476 & 63.1 & OLS \\
\hline Di Matteo & 1997 & $\mathrm{X}$ & $\mathrm{R}$ & 1892 & Ontario & 3476 & 39.5 & OLS \\
\hline Di Matteo & 1997 & $\mathrm{X}$ & $\mathrm{F}$ & 1892 & Ontario & 3476 & 45.6 & OLS \\
\hline Di Matteo & 1997 & $\mathrm{X}$ & $\mathrm{BB}$ & 1892 & Ontario & 3476 & 45.9 & OLS \\
\hline Di Matteo & 1998 & $\mathrm{X}$ & $\mathrm{T}$ & 1892 & Ontario & 3476 & 65 & LOWESS \\
\hline Di Matteo & 1998 & $\mathrm{X}$ & $\mathrm{R}$ & 1892 & Ontario & 3476 & 65 & LOWESS \\
\hline Di Matteo & 1998 & $\mathrm{X}$ & $\mathrm{F}$ & 1892 & Ontario & 3476 & 85 & LOWESS \\
\hline Di Matteo & 2007 & $\mathrm{X}$ & $\mathrm{T}$ & 1892 & Ontario & 3646 & 64.5 & OLS \\
\hline
\end{tabular}

Notes: Type: $\mathrm{X}=$ cross-section, $\mathrm{P}=$ panel; Wealth: $\mathrm{R}=$ real estate, $\mathrm{P}=$ personal property, $\mathrm{T}=$ total, $\mathrm{F}=$ financial, $\mathrm{BB}=$ bank balances 


\begin{tabular}{|c|c|c|c|c|c|c|c|c|}
\hline \multicolumn{9}{|c|}{ Table 2} \\
\hline \multicolumn{9}{|c|}{ New Jersey industrial workers' surveys of job and life expectancies } \\
\hline & \multicolumn{2}{|c|}{ All Industries } & \multicolumn{2}{|r|}{ Glass } & \multicolumn{2}{|c|}{ Textiles } & \multicolumn{2}{|c|}{ Manufacturing } \\
\hline Relevant age & $\mathrm{N}$ & $\begin{array}{c}\text { Mean } \\
\text { (std dev) }\end{array}$ & $\mathrm{N}$ & $\begin{array}{c}\text { Mean } \\
\text { (std dev) }\end{array}$ & $\mathrm{N}$ & $\begin{array}{c}\text { Mean } \\
\text { (std dev) }\end{array}$ & $\mathrm{N}$ & $\begin{array}{c}\text { Mean } \\
\text { (std dev) }\end{array}$ \\
\hline Enter occupation & 188 & $\begin{array}{l}15.91 \\
(2.24)\end{array}$ & 58 & $\begin{array}{l}17.03 \\
(2.20)\end{array}$ & 41 & $\begin{array}{l}14.95 \\
(1.34)\end{array}$ & 25 & $\begin{array}{l}14.76 \\
(2.01)\end{array}$ \\
\hline Declining productivity/capacity & 603 & $\begin{array}{l}41.61 \\
(6.22)\end{array}$ & 237 & $\begin{array}{l}41.41 \\
(4.85)\end{array}$ & 110 & $\begin{array}{l}42.24 \\
(5.99)\end{array}$ & 46 & $\begin{array}{l}39.13 \\
(7.52)\end{array}$ \\
\hline Incapacity to work in occupation & 582 & $\begin{array}{l}56.22 \\
(8.08)\end{array}$ & 233 & $\begin{array}{l}56.06 \\
(6.98)\end{array}$ & 106 & $\begin{array}{l}57.31 \\
(7.35)\end{array}$ & 43 & $\begin{array}{l}48.58 \\
(9.17)\end{array}$ \\
\hline Death & 149 & $\begin{array}{c}66.4 \\
(9.34)\end{array}$ & 53 & $\begin{array}{l}70.32 \\
(6.59)\end{array}$ & 31 & $\begin{array}{l}60.48 \\
(5.48)\end{array}$ & 17 & $\begin{array}{l}56.24 \\
(7.72)\end{array}$ \\
\hline
\end{tabular}




\section{Table 3}

Sample statistics for male-headed, female-headed, and all households

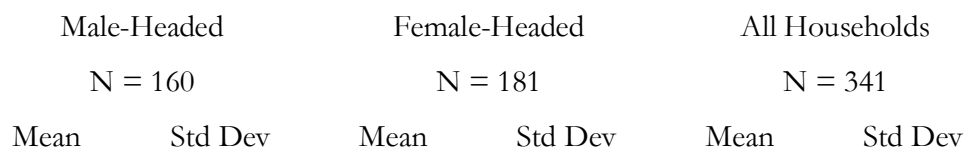

Account balance (\$)

Real balance (\$1890)

Age (yrs)

Spouse's age (if married)

Children present

Children $=0$

Children $=1$

Children $=2$

Children $=3$

Children $=4$

Children $=5$

Children $\geq 6$

Age at initial deposit

Initial deposit (\$1890)

Age at maximum balance

Maximum balance $(\$ 1890)$

Age at account closing

Last withdrawal (\$1890)

A: Variables that change over the life cycle

$\begin{array}{cccccc}336.14 & 324.77^{*} & 301.24 & 286.72^{*} & 317.75 & 305.28^{*} \\ 306.83 & 296.66^{*} & 276.65 & 260.55^{*} & 290.93 & 278.18^{*} \\ 46.08 & 6.15^{*} & 47.35 & 5.67^{*} & 46.75 & 5.90^{*} \\ 46.06 & 6.22^{*} & 53.77 & 5.36^{*} & 49.30 & 5.87^{*} \\ 1.04 & 0.69 & 0.88 & 0.49^{*} & 0.96 & 0.60^{*} \\ 0.61 & & 0.72 & & 0.65 & \\ 0.10 & & 0.06 & & 0.08 & \\ 0.11 & & 0.08 & & 0.10 & \\ 0.09 & & 0.05 & & 0.07 & \\ 0.04 & & 0.02 & & 0.03 & \\ 0.02 & & 0.01 & & 0.02 & \\ 0.03 & & 0.06 & & 0.05 & \end{array}$

\section{B: Variables evolve over the life cycle}

$\begin{array}{cccccc}41.00 & 15.17 & 41.87 & 13.83 & 41.48 & 14.41 \\ 126.54 & 187.49 & 159.11 & 294.84 & 144.47 & 252.42 \\ 45.34 & 16.09 & 47.72 & 15.38 & 46.61 & 15.73 \\ 622.35 & 668.22 & 572.27 & 572.94 & 595.51 & 618.54 \\ 49.38 & 17.02 & 51.23 & 16.28 & 50.37 & 16.63 \\ 335.13 & 496.08 & 313.79 & 474.88 & 323.67 & 484.2\end{array}$

\section{C: Variables that do not change over the life cycle}

$\begin{array}{llll}\text { Born in US } & 0.77 & 0.82 & 0.80 \\ \text { Born in UK } & 0.18 & 0.16 & 0.17 \\ \text { Born in Europe } & 0.05 & 0.02 & 0.03\end{array}$

Notes: standard deviations designated with * are within-individual standard deviations calculated using -xtsum command in Stata. Children over 20 years of age and still in the household are not considered as dependents and no included in calculations. There were few sons and daughters over 20 years in the records and most of those that appear reported an occupation. It is assumed that, although they resided with their parent(s), they were self-supporting.

Sources: author's calculations from CSB (1871-1911) and manuscript censuses. 